\title{
Elinor Wight Gardner: Pioneer Geoarcheologist, Quaternary Scientist and Geomorphologist
}

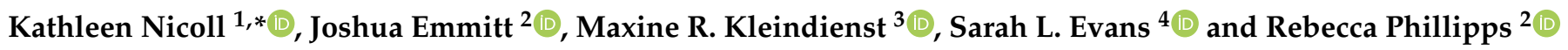 \\ 1 Department of Geography, University of Utah, Salt Lake City, UT 84112, USA \\ 2 School of Social Sciences, University of Auckland, Auckland 1010, New Zealand; \\ josh.emmitt@auckland.ac.nz (J.E.); rebecca.phillipps@auckland.ac.nz (R.P.) \\ 3 Department of Anthropology, University of Toronto Mississauga, Toronto, ON M5S 2S2, Canada; \\ maxine.kleindienst@utoronto.ca \\ 4 The Royal Geographical Society (with IBG), 1 Kensington Gore, South Kensington, London SW7 2AR, UK; \\ S.Evans@rgs.org \\ * Correspondence: kathleen.nicoll@utah.edu
}

Citation: Nicoll, K.; Emmitt, J.; Kleindienst, M.R.; Evans, S.L.; Phillipps, R. Elinor Wight Gardner: Pioneer Geoarcheologist, Quaternary Scientist and Geomorphologist. Geosciences 2021, 11, 267. https:/ / doi.org/10.3390/geosciences11070267

Academic Editors: Suzanne Golding and Jesus Martinez-Frias

Received: 3 May 2021

Accepted: 16 June 2021

Published: 23 June 2021

Publisher's Note: MDPI stays neutral with regard to jurisdictional claims in published maps and institutional affiliations.

Copyright: (c) 2021 by the authors. Licensee MDPI, Basel, Switzerland. This article is an open access article distributed under the terms and conditions of the Creative Commons Attribution (CC BY) license (https:/ / creativecommons.org/licenses/by/ $4.0 /)$.

\begin{abstract}
Elinor Wight Gardner (1892-1981) was the first female geologist who worked and published as a geoarcheologist. During her career, she worked in arid lands of North Africa, Mediterranean and the Near East, and was regarded as a pioneering geoscientist who made important contributions in multiple fields, including archeology, geomorphology, paleontology and Quaternary science. Despite her ground-breaking work at many archeological sites, Gardner's impact has been largely unrecognized. Few details are known about her personal life; she was a private and reserved person who left limited first-hand accounts of her opinions and motivations. Gardner worked with charismatic figures such as her life-long friend and primary collaborator, the archeologist Gertrude Caton Thompson (1888-1985). This biography synthesizes primary sources and draws insights about Gardner's character from her bibliography, publications and notebooks, and mentions by contemporary peers. Much attention has focused on the historical "ancestral passions" of characters working in the fields of geology and archeology, with much emphasis on the 'founding fathers' and significantly less recognition of its 'grandmothers'. We bring attention to the full scope of Gardner's insightful contributions through analysis of her important collaborative research projects linking archeology and landscape studies during the early twentieth century.
\end{abstract}

Keywords: Elinor Wight Gardner; women in science; geoarcheology; archeology; geology; biography; archival research

\section{Introduction}

Although Miss Elinor Wight Gardner (1892-1981) is often cited for her role as a geologist in multiple important studies undertaken with the storied archeologist Miss Gertrude Caton Thompson (1888-1985), Gardner herself was a keen scientist whose contributions remain underappreciated. Gardner documented her own interdisciplinary observations from field surveys and excavations in North Africa, Arabia and across the Mediterranean (Figure 1) and her published contributions remain unparalleled in their excellence and breadth. Caton Thompson and Gardner were two well-educated British women who joined forces around 1924, and consequently spent several decades conducting ground-breaking work, often in very difficult and remote field locales. Working in tandem and as a collaborative team, these women were exceptionally far ahead of their time in recognizing the importance of regional investigations linking geology and archeology. Gardner had already pioneered and employed the intersectional practices of geoarcheology for 50 years before Colin Renfrew declared that "every archeological problem starts as a problem in geoarcheology" [1] (p. 2). 


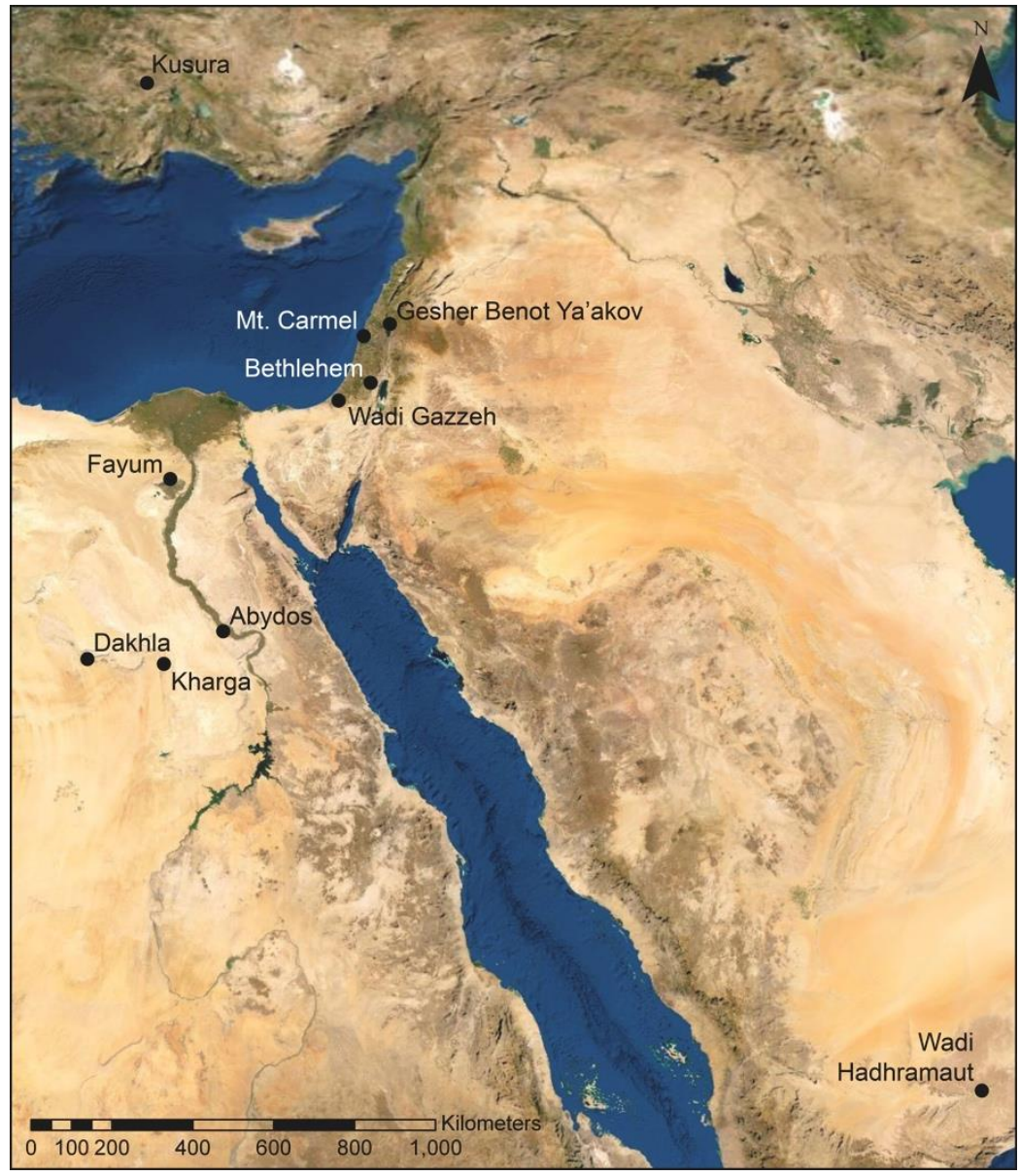

Figure 1. Field sites studied by Elinor Wight Gardner from 1925 to 1938 in North Africa and the Middle East.

Elinor Wight Gardner was the first female geoarcheologist and Quaternary geologist to practice field-based interdisciplinary research, as well as to engage in documenting her own scientific observations as published works. Throughout her career, she collaborated with archeologists, geologists and paleontologists. It seems clear that Gardner was the first university trained and degreed geologist to work as a geoarcheologist in Egypt. Gardner began collaborating with Caton Thompson, who was a well-established archeologist with a focus on Nile Valley and predynastic and prehistoric archeology [2,3], in the Fayum in 1924, conducting extensive research there through 1926, then again in 1928-1929. Around this timeframe, many archeologists were beginning to recognize the importance of linking landscapes with cultural resources; the archeologist and chemist Edmond Vignard worked on sourcing of lithic assemblages in the Kom Ombo plain [4] and around 1925 the Jesuit priest and prehistorian Paul Bovier-Lapierre found lithic artefacts in gravel quarries at Abbasiya, near Cairo [5]. In 1925, the British geologists Kenneth Stuart Sandford and William Jocelyn Arkell were assigned to work on the first prehistoric and river terrace surveys along the length of the Nile Valley, in a project organized by Professor James Henry Breasted, who at that time, was the director of the Oriental Institute at the University of Chicago. These two men became well known for their four-volume synthesis of the Paleolithic of Egypt, published between 1928-1939 [6-11].

Gardner's extraordinary professional career accomplishments included insightful contributions to the published record in multiple fields. Gardner's research presented her geological observations regarding landscape form with the processes that created them, such as fossil artesian vents, dunes and fluvial terraces, and she related these with the locations of archeological sites. Gardner drew inferences about the paleoecology and former climates of sites; she was a "pioneer of the pluvial theory" [3] that described global 
hydrological changes as a function of glaciation cycles during the most recent geological period, the Quaternary. She was one of the first researchers to study desert regions and reconstruct water balance changes and relate them to global glaciations [12].

Although Gardner is mentioned as an important geoscientist of the early-mid 20th century $[13,14]$, she has largely remained an unsung pioneer. Her travels to unknown harsh places suggest that she was an intrepid traveler, keen to see new places, mount expeditions and make discoveries on her own; her maps and publications suggest that she was a meticulous observer and documentarian. Gardner was apparently a private and reserved person who left few self-reflective autobiographical records, a rare exception being her letters home from the 1937 Wakefield expedition, archived in the Royal Geographical Society (with Institute of British Geographers IBG) Collections. We have few photographs of her (Figure 2). Most of what we know about her is drawn from Gardner's professional papers- her own field notebooks, her academic publication record and her many sustained interactions with important scholars who mention her directly-especially Gertrude Caton Thompson, who kept a diary and mentioned "Elinor" often in her autobiography, Mixed Memoirs [15]. In these memoirs, Caton Thompson acknowledged the importance of Gardner's work to her own, and when referring to Caton Thompson's award of honorary Doctor of Literature conferred by the University of Cambridge; Caton Thompson [15] (p. 242) reflected: "But I have never failed to feel that much that I may have accomplished was due to Elinor Gardner's help and to her partnership."

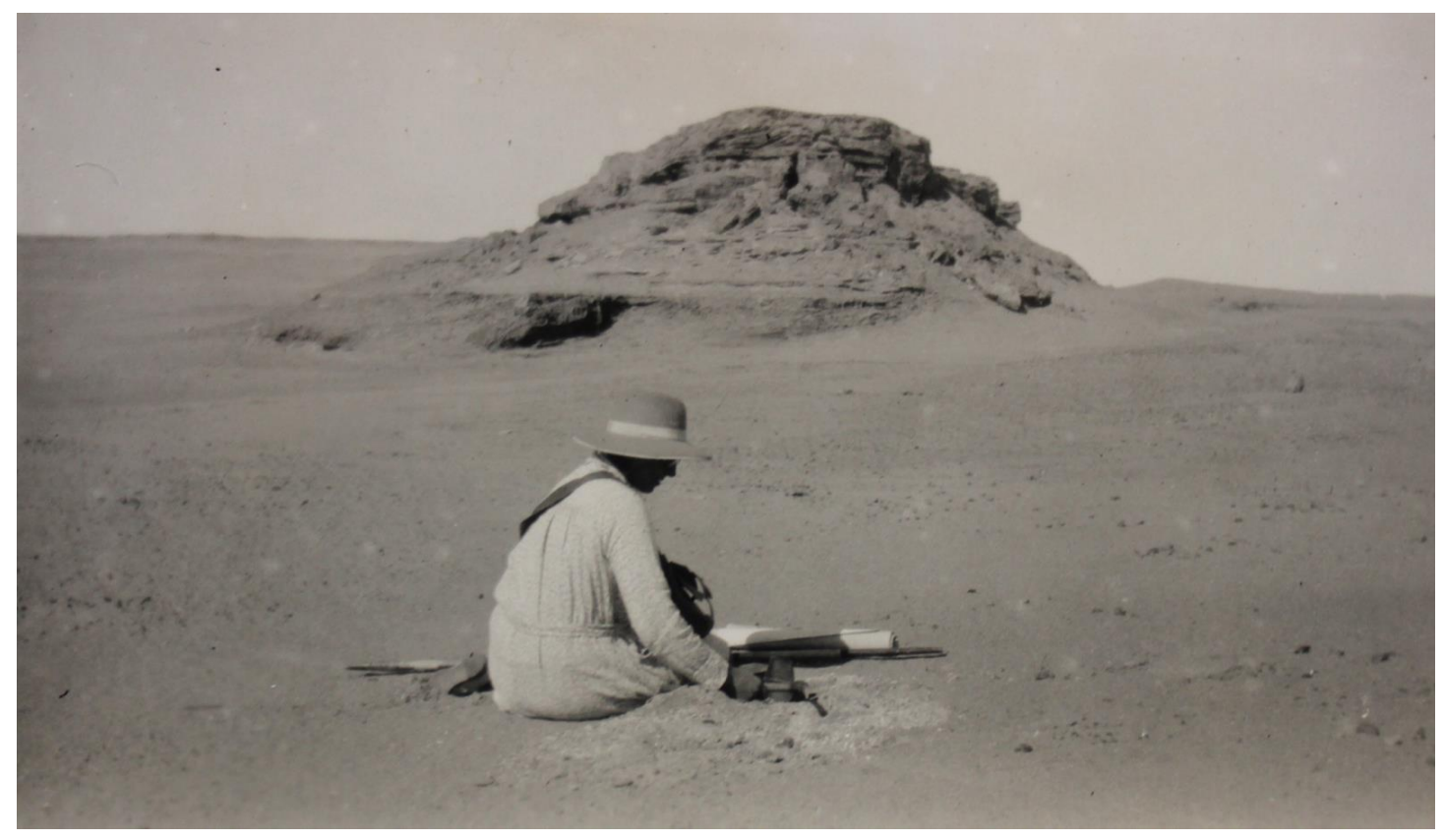

Figure 2. Elinor Wight Gardner in the Fayum. Associated note by Caton Thompson reads "Elinor Gardner with ranging pole taking an unaccustomed rest," corroborating that Gardner was a tireless worker in the field. Image courtesy of University College of London (UCL) Special Collections.

Perhaps Gardner has remained an obscure "lost figure" because her story is so closely intertwined among the well-known figures with whom she worked. She clearly moved in social and academic circles that included many esteemed and charismatic people whose reputations have overshadowed her, especially Gertrude Caton Thompson. Gardner also interacted on projects with many celebrated archeologists, including W.F. Petrie, Dorothy A.E. Garrod, Dorothea M.A. Bate and Winifred Lamb. Although Gardner is often mentioned in their publications, her own name remains relatively unknown today. Indeed, perhaps the reason that no biography of Gardner has yet been compiled is because of how well Gardner integrated her own work with that of others. 
This paper presents an initial biography of Gardner based on the available primary and secondary sources that mention her, including Gardner's own letters, field notebooks and published works as well as well-known materials, including Caton Thompson's autobiography [15]. We demonstrate that Gardner's work was rigorous and cutting-edge, and we describe how her research facilitated new insights and important foundational knowledge because her collaborative approach blended survey geology, Quaternary studies and geomorphology with the established field of archeology. Gardner was among the first women geoscientists to work in the Sahara and to use aerial survey in study of landscapes and prehistoric archeological sites in Egypt and Yemen, and she published photographs of these important perspectives. Gardner's participation in aerial surveys helped document regional study settings where she worked, and clearly provided her with insights regarding the geomorphic evolution of the archeological landscapes she studied.

Elinor Wight Gardner was the first female geoarcheologist, if not strictly the first geoarcheologist to publish interpretations synthesizing both fields. Reframing Gardner as a pioneer helps celebrate her accomplishments; she was a woman scientist who was far ahead of her time. Geoarcheology only truly emerged as a recognized nexus field in the mid-to-late 20th century, as archeology diversified its technological approaches and multidisciplinary interpretive specializations. Yet, in the late 1920s, Gardner's collaboration with Caton Thompson was already practicing geoarcheology-applying the concepts and methods of geoscience to archeological research (definition after Haynes [16]). Gardner brought her geologic insights to archeological work involving field aspects, including sedimentology, stratigraphy, site formation, geomorphic processes and landscape reconstruction of arid regions in particular. She conducted surveys and mapping; she helped prospect for finds and described the provenance of artefacts and lithic sources. Gardner's approaches also included aspects of other disciplines such as geomorphology, paleontology, ecology, zooarcheology or paleobotany. This paper presents observations about Gardner's life and career accomplishments.

\section{Biography}

Elinor Wight Gardner was born on 24 September 1892 to Emilie Montgomery (Atwater) (b. 27 July 1857, New Haven, Connecticut; d. 10 March 1929) and Guy Huggins Gardner (b. 9 April 1853, Richmond, Virginia; d. 13 August 1901, Leek, Staffordshire) [17-19]. Her father worked some of his life in Australia, then was a commission merchant in New Haven, Connecticut. Elinor's parents were married on 22 October 1878 in New Haven, Connecticut and had three children: Captain Guy Atwater Gardner (b. 25 June 1880, New Haven; d. 24 December 1959, Johannesburg); Emilie Montgomery Gardner (b. 30 September 1882, New Haven; d. 8 April 1959, Liphook, Hampshire); and Elinor herself-the only family member to be born in Great Britain. The family moved to England, entering Liverpool on 26 April 1892, six months before Elinor was born in Birmingham.

Little is known about Elinor Wight Gardner's early life. Some context is provided by her mother Emilie Montgomery Gardner's 1920 U.S.A. passport application form filed in the US National Archives, in which she explains that her husband Guy "came to Great Britain to form a company to manufacture steel and iron chains. We intended returning to the United States of America when he got his company running successfully. He died in 1901. My daughter received a scholarship for Newnham College, Cambridge University. I have remained in order to complete my daughter's education" [20].

Elinor Wight Gardner went up to Cambridge 1912, where she read Natural Sciences. During her time at Newnham College, Cambridge, Gardner was influenced (and probably taught) by Dr. Gertrude Elles, the famous geologist and the first woman to be awarded a readership position at Cambridge. It was Elles who helped foster Gardner's interest in geology, and recommended her membership in the Sedgwick Club, the geology society of the University of Cambridge in 1913 [21]. In 1915, Gardner won the scholarship for women at Newnham College, according to the Cambridge Tripos report published in The Scotsman newspaper [22]. 
After her time at Cambridge, Gardner was employed at Stellenbosch University in South Africa as Acting Professor of Geology and was the Head of Department (1917? 19181919) during the end of World War I. She was temporarily hired to replace the geologist and petrologist Samuel James Shand [23], who served in the Royal Engineers, and then was seconded to the British Petroleum Company in Mesopotamia [24] (p.4). During Gardner's time in South Africa, she notably participated in a field trip led by Ernest James Goddard that trekked through the Karoo and into the region between what are now the towns of Price Albert and George [25]. Gardner's move to South Africa may have been influenced by her brother Captain Guy Gardner, who had gone to South Africa as a soldier in the Anglo Boer War in 1899; and subsequently staying on as a farmer in Natal. Guy was interested in archeology, particularly classical archeology, and perhaps this passion influenced his sister Elinor [26]. Guy even accompanied Elinor to the Fayum during the 1927-1928 field season [27] (p. 8). Later, Guy subsequently worked as an archeologist in South Africa at the suggestion of Caton Thompson, where he excavated at Mapungubwe Hill for six seasons between 1935-1940, and later became President of the South African Archeological Society $[28,29]$.

After South Africa, Elinor Wight Gardner returned to England and began teaching at a girls school in Sheringham; while she was employed there, Caton Thompson approached her about working as a geologist in the Fayum [15] (p. 100). Caton Thompson also mentions that prior to her work in the Fayum, Elinor had done "a considerable amount" of fieldwork. Details remain unknown, but are likely related to her Natural Science training while at Cambridge [30] or in South Africa. In 1925, Gardner undertook the Royal Geographical Society (RGS) course in surveying, after Caton Thompson approached them on her behalf [31,32]. This foundational training taught Gardner essential skills for creating contour elevation maps, which she deployed throughout her fieldwork in the Fayum in the late 1920s and during the 1930s when she worked at Kharga Oasis in Egypt, as well as in Anatolia, Palestine and the Arabian Peninsula. She approached all her field projects with a surveyor's perspective.

In addition to cartography, Gardner was talented at field drawing, and she often was the photographer on expeditions. She took most of the pictures during her and Caton Thompson's work in the Fayum, as well as during subsequent projects in Egypt and at the Hadhramaut in Arabia [33] (p. xiii). Because Gardner was typically behind the camera lens documenting science, hardly any photos exist of her, at least compared to other contemporary figures. We have not yet found any studio portraits of Gardner like we have of female contemporaries Caton Thompson and Garrod; this may be the case because Gardner was from a merchant-class background. Confirmed photos of Gardner in the field show her at work, or during reportedly brief moments of rest (Figure 3).

During her career, Gardner held a number of academic positions, according to a 1975 note by Caton Thompson appended into Gardner's field notebook, which seems to present a summary list of Gardner's main accomplishments [34,35]. Following her professorship at Stellenbosch University in South Africa, she became a Research Fellow at Lady Margaret Hall at Oxford and was appointed as Lecturer in Geology at Bedford College, London from 1926-1930, under Professor Hawkes, F.R.S.. At this time, Gardner was still working in Egypt with Caton Thompson, first in the Fayum and then in Kharga, but was able to compound her leave for the 1927-1928 Fayum fieldwork, and subsequently Gardner was promised leave in winter of 1929-1930 to work at Kharga in Egypt [15] (p. 102,112). During her position at Bedford College, there was an issue with the Fayum concession (discussed below), and Gardner was part of the decision with Caton Thompson to move to another study area in the Fayum in 1927-1928.

In 1929, Gardner was elected Fellow in the Geological Society of London, and in 1930 she was made a Fellow in the Royal Geographical Society. In November 1930, Gardner was awarded a six-year research fellowship from the Senior International Fellowship at Lady Margaret Hall at Oxford. This fellowship allowed her to continue working in Egypt and in excavations at Kharga with Caton Thompson. In the early 1930s, Gardner successfully 
raised some of her own research funds from the British Association and the Geological Society's Gloyne Outdoor Fund. As a result, she was able to publish a number of highprofile articles [36-39] and The Desert Fayum in 1934, co-authored with Caton Thompson.

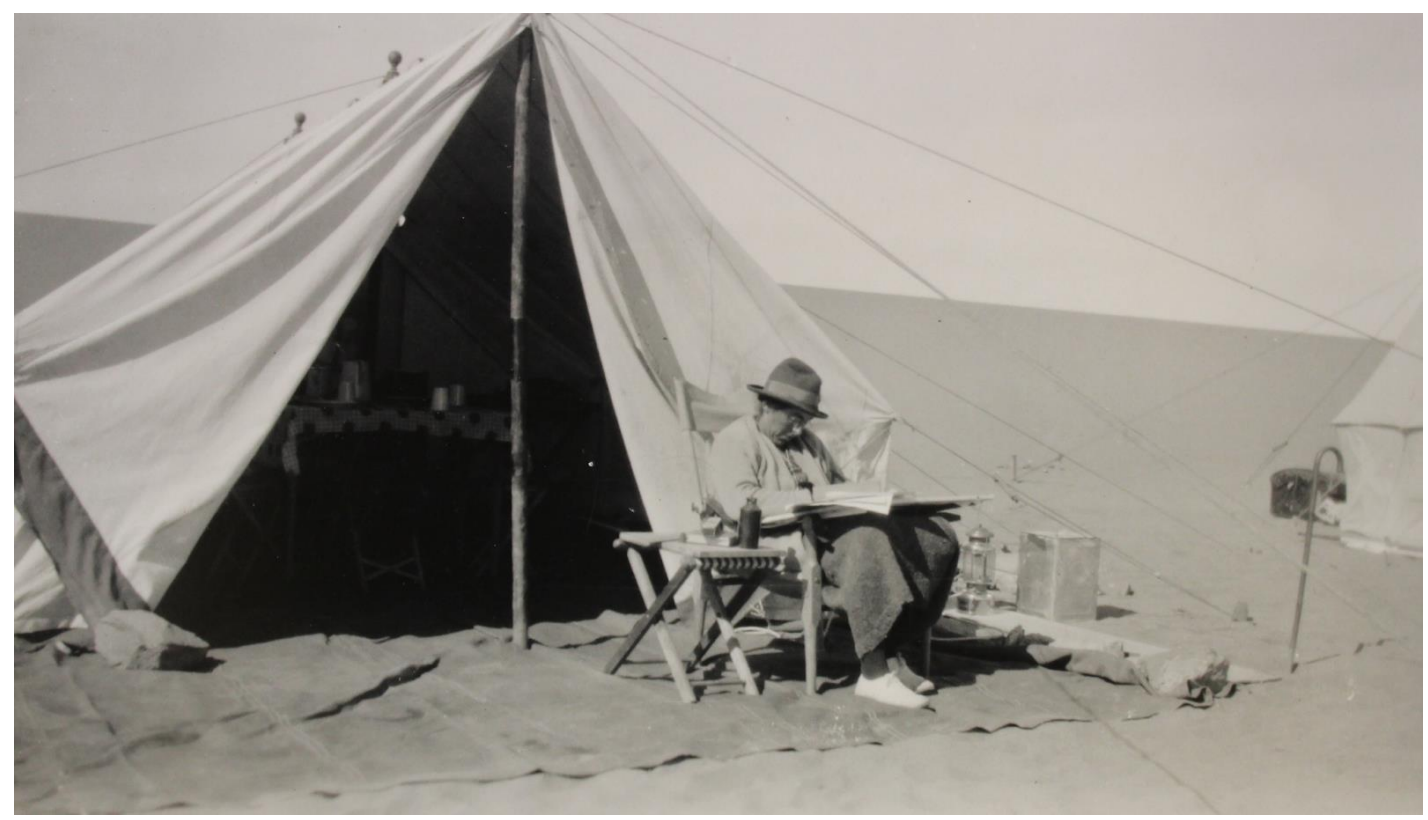

Figure 3. Elinor Wight Gardner in the Fayum. Associated note by Caton Thompson reads “Elinor Gardner outside tent at home." Image courtesy of UCL Special Collections.

In 1935, Gardner conducted fieldwork in Anatolia with another colleague who was a life-long friend from her time at Newnham College in Cambridge, Winifred Lamb. Lamb and her mother Mabel were also family friends of Caton Thompson. Later, Mabel Lamb would bequeath Elinor and her sister Emilie 'The Bothy,' a stone-built cottage at Borden Wood in West Sussex, for the duration of their lifetime [15] (p. 198). Following her work with Lamb in Anatolia, Elinor was awarded a Senior International Research Fellowship from the British Federation of University Women from 1937-1938, which allowed her to conduct fieldwork in the Hadhramaut in Arabia.

As her funding ended in 1938, Gardner faced financial pressures and limited prospects for employment in either geology or archeology; World War II was unfolding, and this was a time of increasing tensions. Unable to pay her membership dues, she resigned both of her fellowships in the Royal Geographical Society and Geological Society, effective in January 1939 [40]. There were stressful local politics and violent outbursts contributing to tense circumstances around the end of her work at the Bethlehem excavation, when James Leslie Starkey took over the control of the site from Dorothea Bate. Gardner and Bate continued to work at the site with Starkey as the official head. Tragically, at the beginning of 1938, Starkey was shot and killed, the reason for which is debated [41]. As news of the murder reached Gardner during her work in Hureidha (Hadramaut), Caton Thompson [15] (p. 189) described it as "personal loss and shock"; Gardner said she was 'horror-struck' as she wrote home. After Starkey's death, Gardner refused to continue working at Bethlehem with anyone but Bate in charge. Unfortunate circumstances ultimately forced their excavations to close: local reports from Palestine attested to escalations of violent conflicts and the imminent threat of war with Germany, and Bate was not granted a leave of absence from the Natural History Museum, London, to conduct the work planned for March 1939 [42] (p. 274).

Following these tragic events, Caton Thompson [15] (p. 198) wrote " ... Gardner also, looking for a more settled life ... had exhausted the financial possibilities, and she decided to devote herself to horticulture." Throughout her geological and academic career, Elinor had always pursued some research-related interests in botany; from 1938-1941, she 
was Assistant Curator at the Royal Botanical Gardens in Edinburgh. In 1942, Gardner was able to train at the Waterperry Horticultural School. During World War II, she returned to Lady Margaret Hall at Oxford, where she tended the vegetable production. Then she became Steward of the Offley Gardens near Hitchin in 1945 [15] (p. 198). Gardening courses were offered at Offley Gardens and during her time there Gardner supervised students tending their plots [43] (p. 38). During and after this time, Caton Thompson notes in her autobiography Mixed Memoirs [15] that Elinor had something to say about the state of other people's gardens, and that her own was always well-presented. In the Wakefield letters, Gardner regularly talks about her garden and how well (or not) it was being kept. During her leisure time, when she was not exploring local geological features, Gardner often looked for particular flowers in bloom. Caton Thompson [15] (p. 298) noted that on a trip to Cape Saint-Vincent, Portugal, after looking at a limestone formation, they came across a patch of wildflowers where they "loitered." On another trip together to Wester Ross, Scotland, Caton Thompson [15] (p. 327) notes "it was a great gain for me to be with a qualified geologist."

After Garner's retirement from Offley Gardens in 1952, there are no subsequent employment records for her. Caton Thompson's memoirs [15] (p. 302) record some additional information about Gardner: when she resided at the Bothy, Gardner lived with Margaret Rees and a cat who was "an adorable tabby named Tibby." In 1974, Gardner moved from the Bothy to a house in Petersfield in Portsmouth, Hampshire, where she remained until her death at age 89 on 30 December 1981 [17,18].

We present an overview of Gardner's education and employment, and some highlights of her fieldwork (Table 1), drawn from multiple sources including Caton Thompson [15,34], Harvey and Ogilvie [30] and Turner [14].

Table 1. Elinor Wight Gardner's education and career overview.

\begin{tabular}{|c|c|}
\hline \multicolumn{2}{|l|}{ Education } \\
\hline & Edgbaston High School, Birmingham \\
\hline 1912-1916 & Newnham College, Cambridge \\
\hline 1915 & Natural Science Tripos, Part 1, Class 2 \\
\hline 1916-1917 & Bathurst Student \\
\hline 1926 & M.A. Cambridge \\
\hline 1942-1944 & Waterperry Horticultural School, Trainee \\
\hline \multicolumn{2}{|c|}{ Professional positions } \\
\hline 1917? 1918-1919 & Stellenbosch University, South Africa, Acting Professor (Head of Department) \\
\hline \multirow[t]{2}{*}{ 1926-1941 } & Cambridge Associate \\
\hline & Lady Margaret Hall, Oxford, Research Fellow in Geology (after WWI) \\
\hline 1926-1930 & Bedford College, London, Lecturer in Geology \\
\hline 1929-1939 & Royal Geographical Society, Elected to Fellowship \\
\hline 1930-1939 & The Geological Society of London, Elected to Fellowship \\
\hline $1930-1936$ & Lady Margaret Hall, Oxford, Research Fellow \\
\hline 1937-1938 & British Federation of University Women, Senior International Research Fellow \\
\hline 1938-1941 & Royal Botanical Gardens, Edinburgh, Temporary Assistant Curator \\
\hline 1941-1945 & Lady Margaret Hall, Oxford, Director of Vegetable Production \\
\hline 1945-1952 & $\begin{array}{l}\text { Froebel Educational Institute, Offley Gardens, Hitchin, Garden Steward and } \\
\text { Lecturer }\end{array}$ \\
\hline \multicolumn{2}{|l|}{ Fieldwork } \\
\hline 1917? 1918-1919 & South Africa \\
\hline $\begin{array}{l}1925-1926, \\
1927-1928\end{array}$ & Egypt: Fayum Desert \\
\hline 1930-1933 & Egypt: Kharga Oasis and Nile Valley \\
\hline 1935 & Anatolia: Kusura \\
\hline 1935 & Palestine: Coastal/Inland Reconnaissance \\
\hline 1935-1936 & Palestine: Bethlehem \\
\hline 1938 & Palestine: Wadi Ghazzeh \\
\hline 1937-1938 & Yemen: Hadhramaut Expedition \\
\hline
\end{tabular}




\title{
3. Fayum: Fieldwork in Egypt Commences
}

\author{
Geographer Karl Butzer stated [44] (p. 2):
}

"A watershed was crossed in the 1920s, when geologist Elinor W. Gardner began to work with archeologist Gertrude Caton Thompson in the Fayum Depression of Egypt .... By building site clusters into a multidimensional landscape, Caton Thompson and Gardner ... had broken new ground, setting a strategic research direction that anticipated geoarcheology. Equally so, their model of collaborative research showed what could be done and how."

Gardner began working with archeologist Caton Thompson in the Fayum in Egypt in the year 1925. Gardner had been recommended by Dr. Gertude Elles and Dr. John Edward Marr at Cambridge after Caton Thompson struggled to find a colleague who could, or would, work with her, given that she was a single woman. Their fortuitous association began a working relationship between the two women that would define most of their future field and academic work together. Theirs were the first interdisciplinary regional studies undertaken to investigate settlement patterns in Egypt [45] (p. 186), and they delivered highly-regarded African prehistoric research. In addition to initiating the practice of geoarcheology, they also incorporated elements of what would be later be defined as landscape archeology.

During their fieldwork in the Fayum, Gardner leveraged her geological training and she surveyed to create a contour map at 10ft $(\sim 3.05 \mathrm{~m})$ intervals of the approximately $259 \mathrm{~km}^{2}$ concession (Figures 4 and 5). In addition to topographic features, her map also recorded the position and extent of the discovered archeological sites (including surface scatters). Survey and mapping occupied most of Gardner's time during her first season in the Fayum in 1925-26. While the interpretation of the features she recorded may have changed over the years, the general accuracy of Gardner's maps are superb, and contemporary workers still refer to them, particularly as the Fayum has become increasingly disturbed and developed (see, for example: [46,47]).

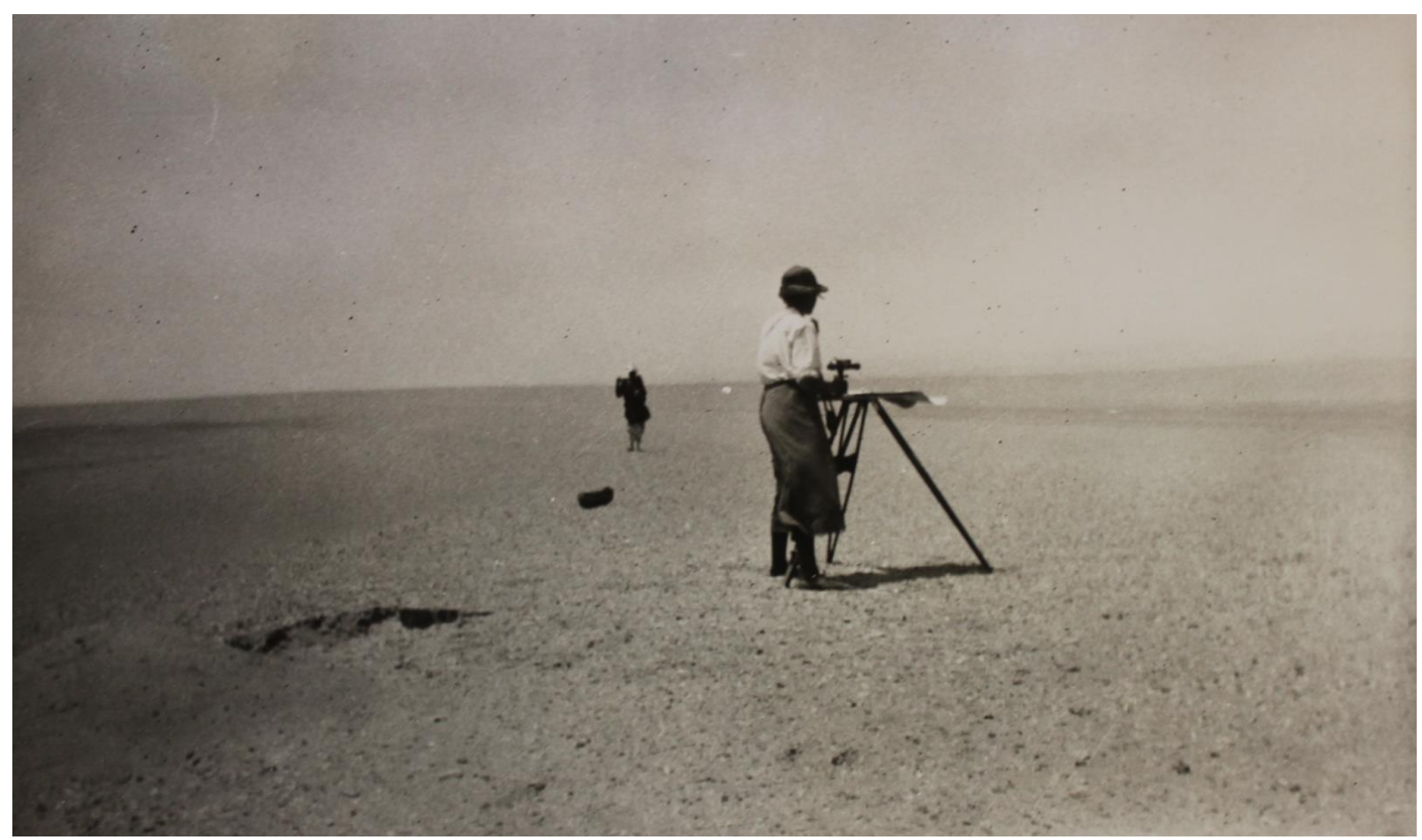

Figure 4. Fayum. Elinor Wight Gardner conducting a survey of the concession area between Kom Ashim and Qasr-es-Sagha to generate a contoured map. Associated note by Caton Thompson reads "High mid. day winds and dust were often a trouble." Image courtesy of UCL Special Collections. 


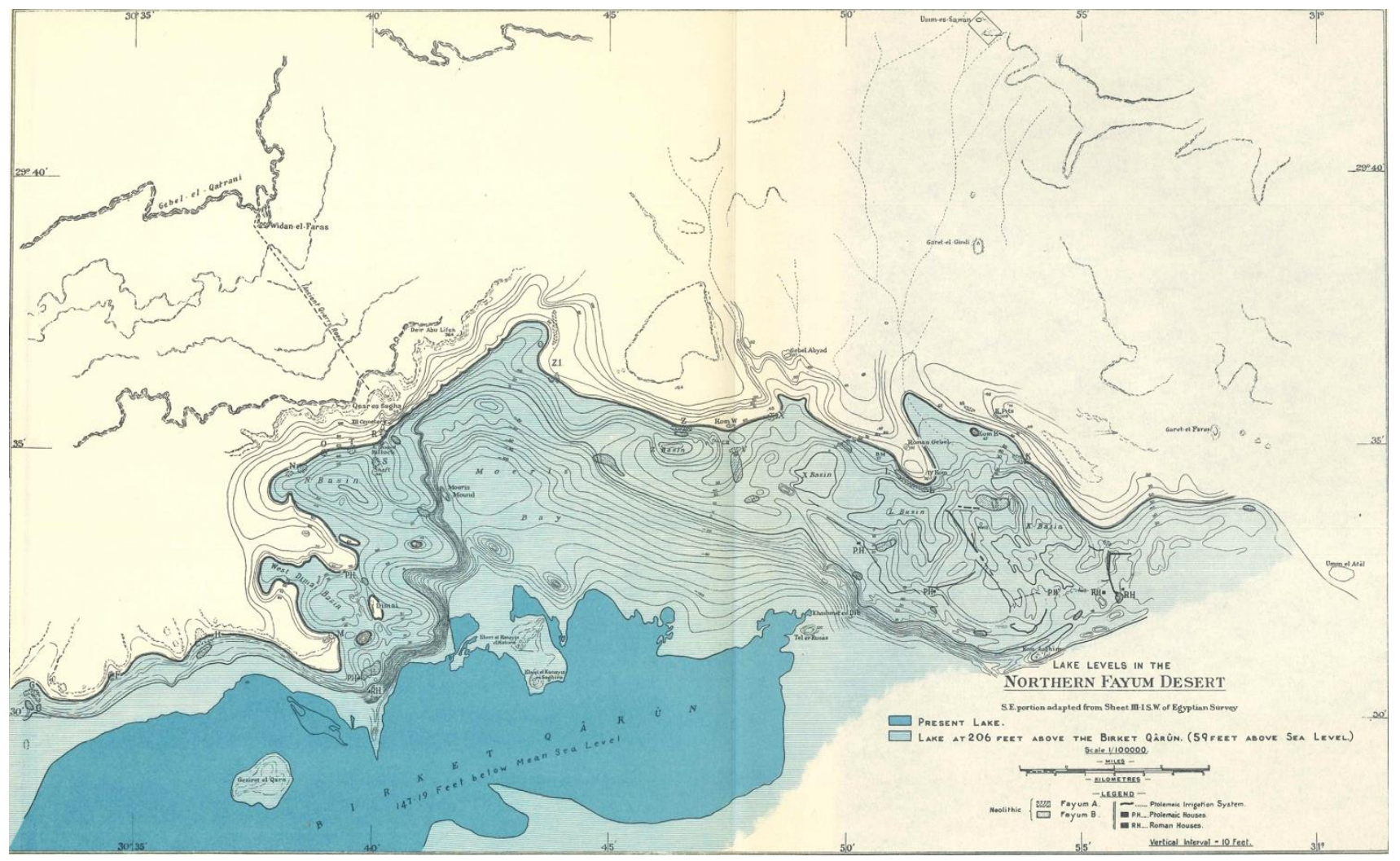

Figure 5. Example of one of the contour maps created by Elinor Wight Gardner of the Fayum Depression. After Caton Thompson and Gardner [26] (p. CXI). Image used with permission of the Royal Anthropological Institute. (RAI).

In the Fayum, Gardner worked on reconstructing the Pleistocene landscape from survey of the plateau escarpment forming the depression margins and detailed studies of the sediments and paleontological remains. The papers she published (e.g., [48-52]) were definitive for the time, eloquently describing the geological origins of the landscape, and the evolution of the landforms and its lakes. Gardner also used recovered mollusks for making paleoecological and environmental inferences; her work [37] is so well known by malacologists that the modern worker Turner [14] regards her as a paleontologist.

Gardner's reconstruction of the middle Holocene lake levels were an integral part of Caton Thompson's cultural interpretation of the Fayum. Gardner identified two lakes she labeled as the Pleistocene and Neolithic based on a comparative study of gravels, lacustrine fauna and correlation with Nile gravels $[48,50]$. The connection between human behavior during the Pleistocene and early Holocene with changes in the levels of Lake Qarun contributed to later syntheses of the prehistory of this period. Childe was likely influenced by the connection between socio-economic change and climatic shifts in his Neolithic Revolution model. Given the paucity of examples of Neolithic occupation in Egypt at this time, the work of Caton Thompson and Gardner serves as an important example of the relationship between cultural change and climate. For example, in New Light on the Most Ancient East [53] (p. 41), Childe particularly mentions the shrinking of the lake and culture degeneration (Fayum A-Fayum B).

Details of the interpretations made from Gardner and Caton Thompson's work were later challenged by Fred Wendorf and Romuald Schild [54]. Despite this, however, Gardner's work remains recognized as unparalleled and as an important first step for understanding of the early and middle Holocene occupation of the Fayum north shore [46].

Correspondence between Caton Thompson [15] and Wendorf articulates a typical discourse surrounding established ideas as further work and methods provide new insights and interpretations. Letters communicated Wendorf's wish to dedicate the 1976 publication Prehistory of the Nile Valley [54] to Caton Thompson, a request to which she 
eventually agreed, at Gardner's urging [15] (p. 340). Caton Thompson [15] (p. 339) eventually accepted most of Wendorf's interpretations of the lake levels, but one main point of unspoken contention may have been their criticism of the results of Gardner's interpretations, which had been exacerbated by the issues with concessions in the Fayum. On this, Caton Thompson [15] (p. 339) states:

"It must in fairness be remembered that Gardner spent most of her first season with me mapping sites then unrecorded, and contouring at $3.05 \mathrm{~m}$. about 100 square miles of the former lake shore. During her second season we were deprived by Professor Breasted's ill-advised move to take over our former concession, thus bringing to an end our plans to excavate in greater detail the geographically more sensitive areas."

In addition to her work on the lake levels, Gardner was also responsible for some of the most important discoveries in the Fayum: early evidence of domesticated wheat and barley discovered during the 1925-1926 season in the Upper K Pits, and later found in the Lower K Pits [27] (p. 41, 52). Further work on this area and the lake level reconstructions of the north shore were interrupted by Breasted and Sandford, who usurped the north shore concession from Caton Thompson, forcing the women to move to adjacent areas. It was during her participation in this later 1927-1928 season that Gardner took leave without pay for a year; she excavated the irrigation channels that were highlighted by weeds growing in linear patterns following unusually high rainfall in the area. This excavation was complemented by some Roman houses attributed to the time of Ptolemy II by Gardner's brother, Guy, therefore, attributing the irrigation channels to that period. The excavation of the irrigation channels was done completely by Gardner and her workmen, with Caton Thompson providing a historical overview in the publication [15] (p. 105).

\section{The Western Desert of Egypt: Kharga Oasis and the Nile Valley}

\subsection{Kharga Oasis}

During the 1930s, Gardner joined Caton Thompson to document the prehistory of Kharga Oasis in Egypt. As she did in the Fayum, Gardner played a key role as they worked to map and study the stratigraphic associations of multi-period archives at spring sites, structures and other contexts with "finds" of fresh lithic fragments, pottery shards and other cultural artifacts. After a brief visit to Kharga in 1928, Caton Thompson had recognized the importance of prehistoric occupation of the area and she obtained the concession for the entire Oasis, a very large area within the northeastern African Sahara. Caton Thompson raised funds and organized the Royal Anthropological Institute's Prehistoric Research Expedition, commencing fieldwork survey and excavations in Kharga with Gardner in 1930.

In the 1930s, the Western Desert Railway connected Kharga oasis to the Nile Valley. But Caton Thompson and Gardner accessed their study area by camel, following trails and dirt tracks across the rugged limestone plateau. Perhaps they made this choice to develop a better understanding of the landscape to recognize cultural features, and to facilitate their mobility for surveying in the oasis region. Their expedition in Kharga concentrated on documenting Pleistocene and Holocene prehistory, as well as some locations with material from the historic period, especially those relating to hydrology. Over the course of three field seasons, Caton Thompson and Gardner used camels for longer trips, and for provisioning field camps (e.g., [55]) with food and water from Kharga town and wells. This support required a camel herding crew, as well as a cook and local people who assisted in the survey and excavation.

The many publications, and three of Gardner's field notebooks, suggest that Caton Thompson was the initiator, organizer and fundraiser, while Gardner actually conducted most of the Kharga fieldwork (e.g., [36,39,56,57]). Despite this labor division, Gardner's real contribution is often under-represented. She was the one who did the majority of the fieldwork. Gardner was also the sole participant in the 1932-33 field season, sending the lithic finds back to Caton Thompson in England [58]. This seems to have been their normal pattern; Gardner noted in a letter home from the later Wakefield expedition to Arabia, 
during a period where she had to take charge of logistical matters, that "It seems a strange reversal of functions to be with C.T. \& doing all the arranging etc!" [59].

Caton Thompson's notes in the report on the 1930-31 season [60] (p. 77): “Miss E. W. Gardner, F.G.S., now Research Fellow at Lady Margaret Hall, was again my valued colleague, and her geological work, ... promises a peculiarly rich harvest in Pliocene and Pleistocene geology." However, in her report on the second season of work, Caton Thompson refers to 'we' throughout, but the only actual reference to Gardner is as a photographer on one figure ([56]: Plate F). The 1952 monograph Kharga Oasis in Prehistory is solo-authored by Caton Thompson [57], although Gardner [61,62] wrote important parts on geology and site settings. Caton Thompson's [60] extensive annotations of Gardner's notes about her 1931-1932 lowland surveys demonstrate how much she used Gardner's work.

After their co-authorship of The Desert Fayum and their collaborative publishing about the Kharga field seasons throughout the 1930s, the subsequent lack of representation of Gardner as a co-author with Caton Thompson is notable. Specific reasons remain unclear. We can only speculate about why Gardner was not named as a co-author with Caton Thompson in the 1952 book Kharga Oasis in Prehistory. The Kharga manuscript was mostly written between 1932 and 1934 [57] (p. vi), but publication of the book was much delayed due to various problems (pp. xiii-xiv). During World War II, the manuscript was kept in the Royal Ontario Museum, Toronto. By 1945, Gardner was employed at the Froebel Educational Institute, Offley Gardens and she had basically ended her academic career. It could be that Gardner might not have wanted much to do with the final preparation of the volume, but details are lacking from their own correspondence or other primary documentation. Caton Thompson's autobiography [15] never mentions friction or a schism between the two women at any time, and friendly correspondence between them throughout their lives survives in the Gardner archives at the Royal Geographical Society (with IBG).

There is no doubt that Gardner was critical to the entire operation of all fieldwork in Kharga-both logistically and scientifically. In 1932-33, Gardner [58] dealt with organization and day-to-day details, and she also surveyed and mapped much of the oasis on foot, aided by camels, two assistants and an Egyptian crew. Gardner traversed difficult, high relief terrain with her heavy equipment to collect measurements along transects from the high northwestern jebels (mountains or hills in Arabic) toward lowlands, and then toward the eastern plateau forming the edge of the Kharga Oasis. Her mapping and survey was plodding, dusty and exhausting; the effort required fitness, careful footing and commitment to ascend steep slopes strewn with large boulders of dark weathered limestone that got hot in the sun (Figure 6).

Gardner's remit to map the imposing and remote terrain around Kharga Oasis benefited greatly in February 1931 when the renowned aviator Lady Mary Bailey visited with her DH 80a Puss Moth airplane. Caton Thompson and Gardner had initially created a landing strip in a flat area. Although the ground was not rocky, it was sandy, so they watered the sand to compact it, and then they walked camels around the area for two days to mark the location [15] (p.149). But this area proved too dusty and soft for safe landings, so they set off by camel for an hour to consult with the local Governor, who permitted them to use the ground used by the Flying Corps during the 1914 War [15] (p.150). Over a fortnight of attempts, and after four days lost to bad weather, Lady Bailey was able to fly around Kharga Oasis and Dakhla at low elevation on 24-27 February 1931. Gardner joined the pilot and flew over the study area, taking photographs. Gardner's field notebook recounts the visibility and details of the flight path as well as the camera settings (f stops and apertures), altitudes, viewshed aspects and locations depicted for the aerial photographs she took [35] (pp. 1-11). Many of these photographs are among the first aerial photographs published from Egypt, and are included in the plates of the book Kharga Oasis in Prehistory and other publications. 


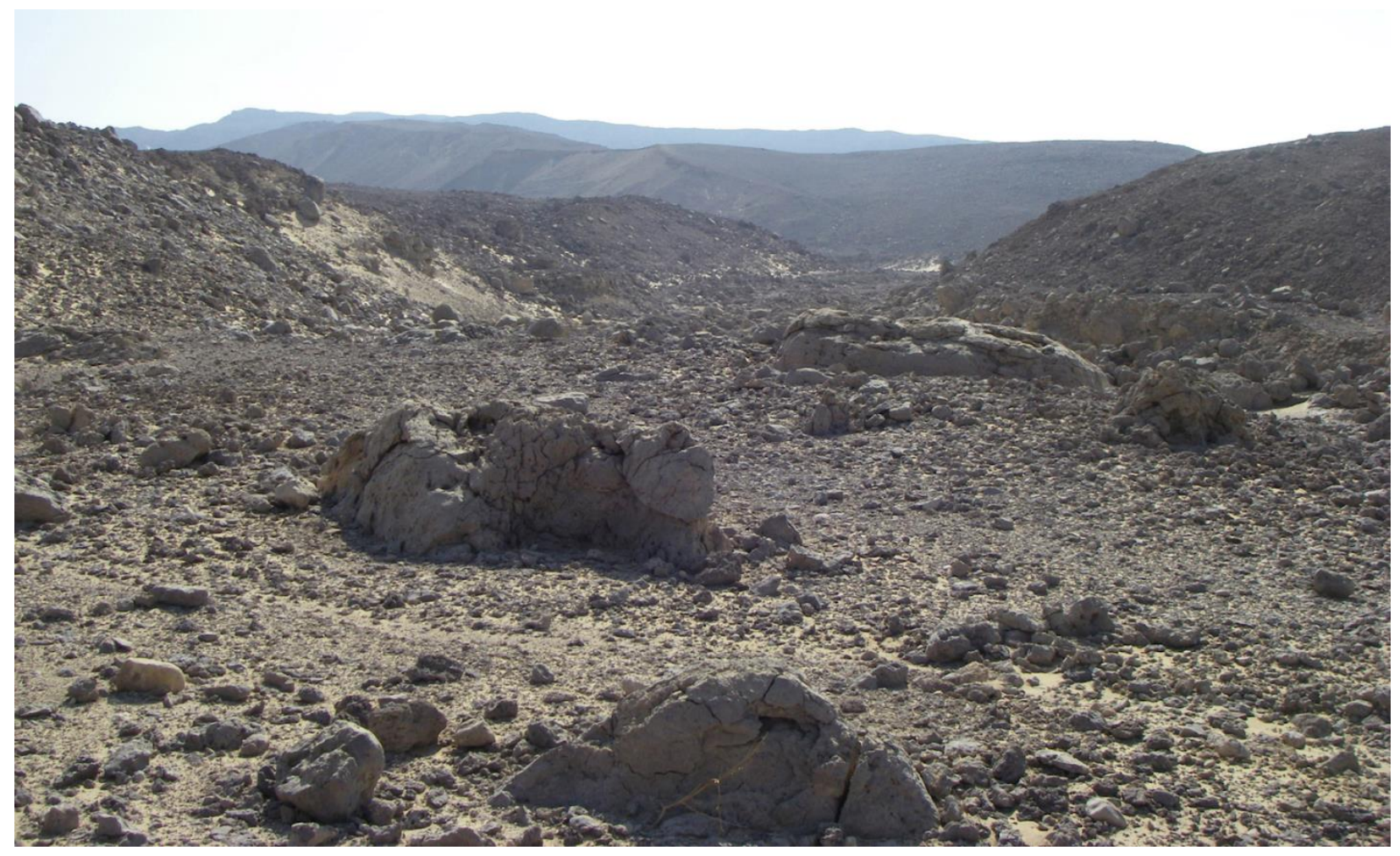

Figure 6. Steep terrain with Quaternary sediments mapped by Gardner 1931-1932, looking southeast from camel trail up toward the escarpment face (Photographed by MRK in 2011). The dark rocks are angular and sharp, and get hot in the desert sun, creating a very challenging surface to walk on, even for camels.

Gardner was the first to make scientific investigations of Pleistocene and Holocene contexts along the Plateau and the eastern escarpment known as the Sinn el Kiddab northeast of Kharga. Despite very challenging terrain, she mapped artefact locations, paleospring tufas and surficial deposits of the Bulaq Pass (Figure 7). Gardner traversed the region from Gebel Yebsa $\sim 100 \mathrm{~km}$ south to Mata'na, regretting she could progress no further because of logistical problems and lack of time. At Refuf and Mata'na, Gardner found and excavated the two in situ localities representing a Younger Middle Stone Age ('Upper Levalloisian') cultural unit (Figures 8 and 9).

Even while working on her own to document the geomorphology, Gardner and her crew found and identified archeological localities throughout Kharga Oasis. During the years 1930-1932, Gardner reported the sites for Caton Thompson's attention, and if Caton Thompson judged the finds as archeologically important, the women combined their excavation efforts and Caton Thompson analyzed the finds. During the years 19321933, when Gardner was out doing fieldwork and Caton Thompson was not present in Egypt, archeological analyses were limited to what Gardner chose to collect and ship to London; Gardner's own recorded field observations were critical primary data for Caton Thompson. Gardner's notes meticulously recorded who found what, and she documented scattered surface evidence and isolated finds, as well as concentrations and the few buried finds-these are some details that even modern surveys do not often record. 


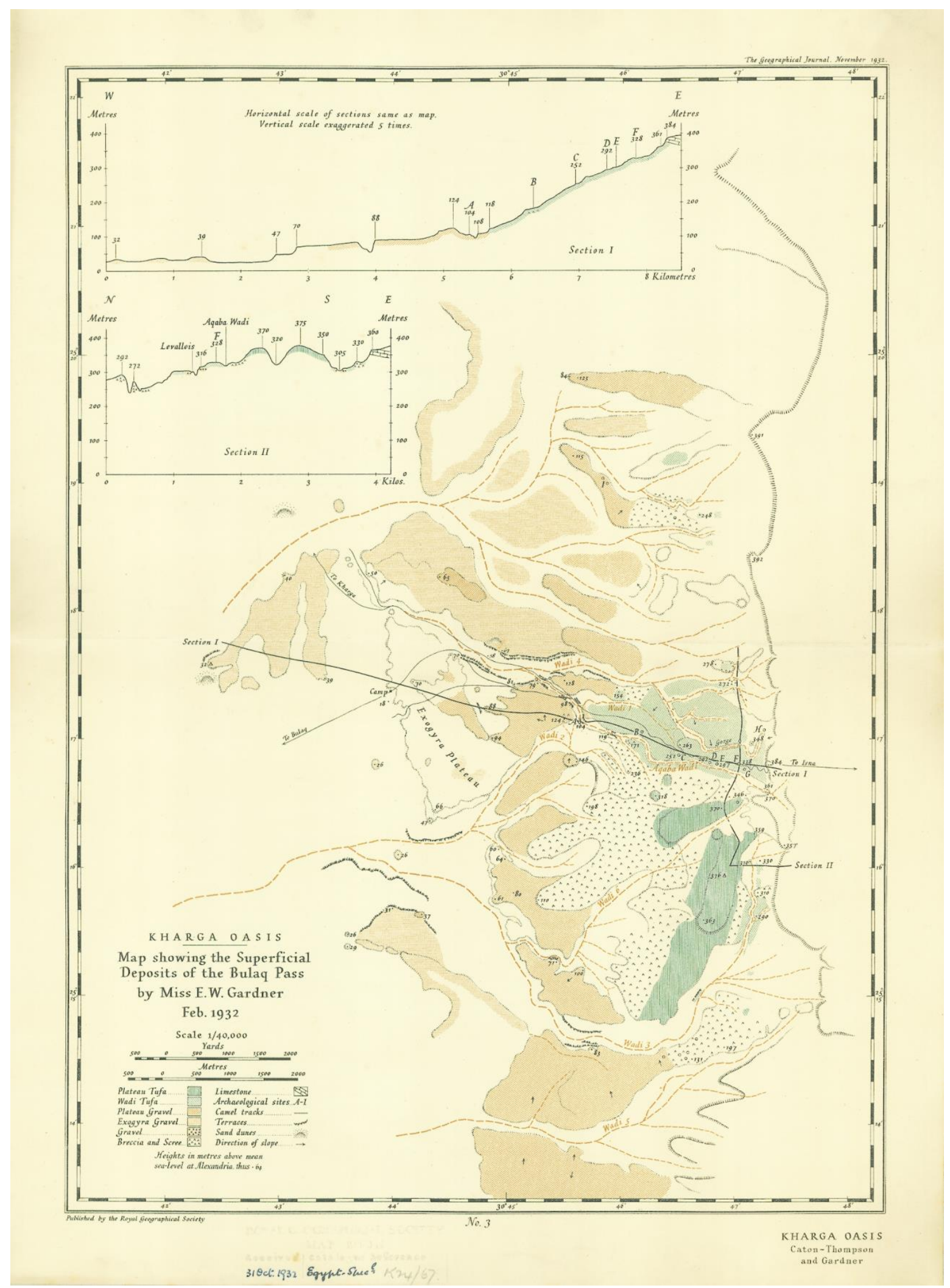

Figure 7. Paleospring tufas mapped in "Kharga Oasis. Map showing the Superficial Deposits of the Bulaq Pass by Miss E. W. Gardner Feb. 1932" Scale 1:40,000. Published by the Royal Geographical Society in 1932 [63]. Used with permission of RGS with IBG. 


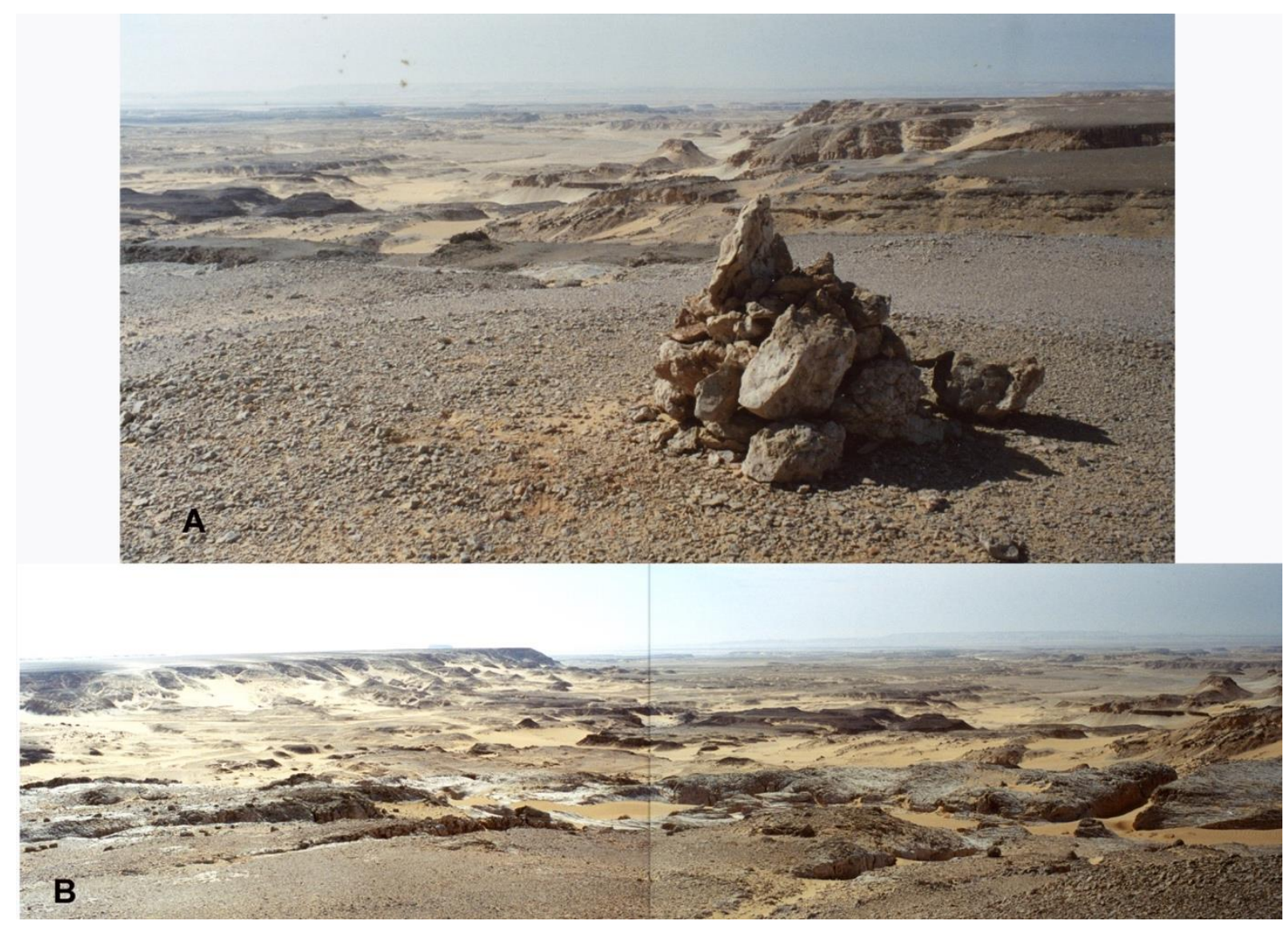

Figure 8. Upper Wadi el Refuf, Sinn el Kiddab escarpment, Kharga Oasis, Gardner's key locality for the paleospring tufa chronology. (A): Gardner's cairn at crest of Gebel Refuf, north rim of wadi, looking west. (B): Composite of upper wadi from north rim below cairn, looking south and southwest. Dark masses are tufa outcrops. Photographed by MRK in 2006.
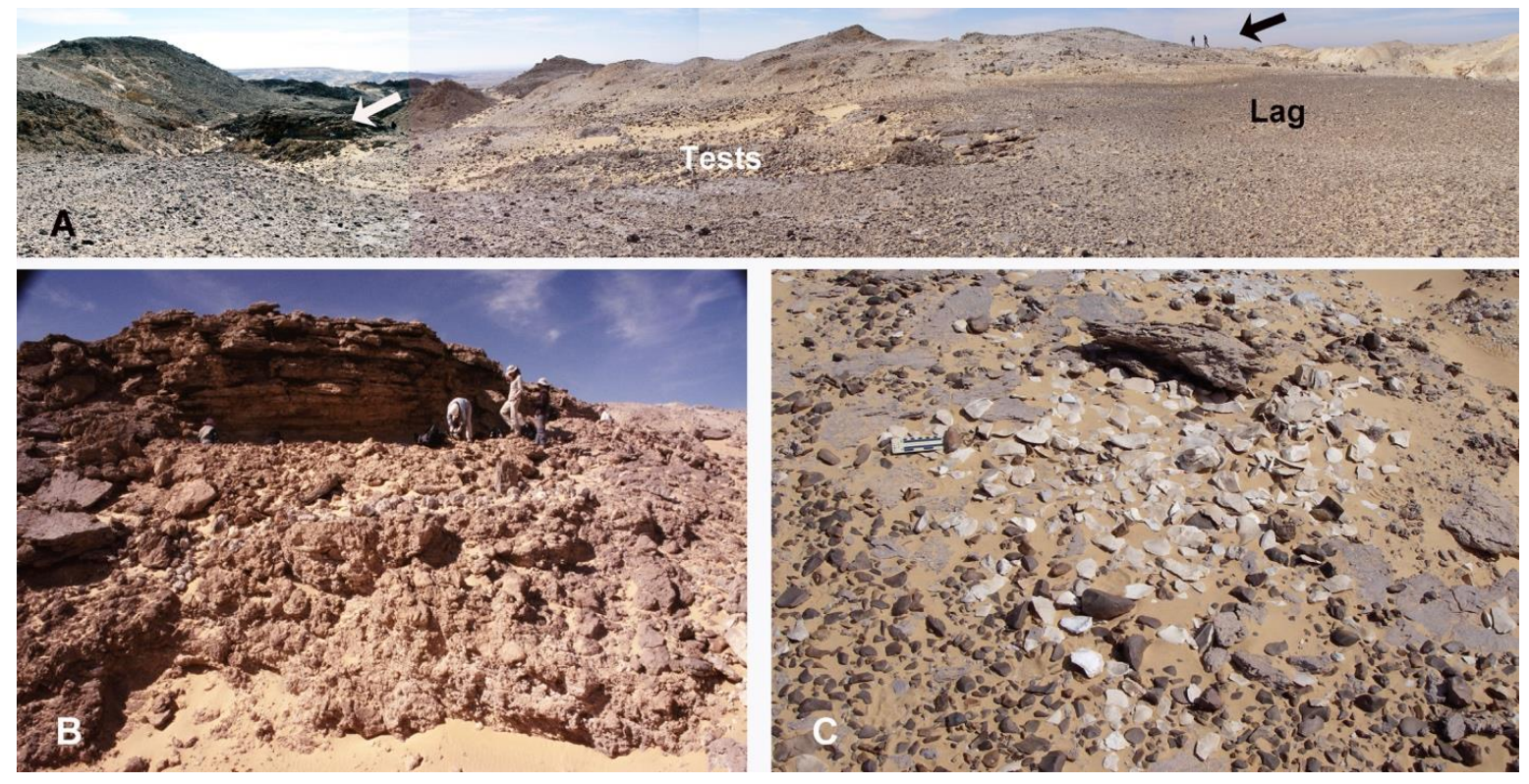

Figure 9. North Mata'na area, high on the escarpment, Gardner's locality 'G' with Younger Middle Stone Age 'Upper Levalloisian' lithics in situ. (A) Composite view, looking west. Main excavation in tufas (white arrow); series of small test pits on slope, not reported in notes or publications; figures on skyline investigating Esna shales that have large chert nodules outcropping (black arrow). (B) Main excavation with bedded silts between two tufa deposits dating to Marine Isotope Stage (MIS) 5. (C) Gardner's 'waster pile' found at one of her test pits. Photos taken by author MRK in 2006. 
As they aimed to establish the first chronology for the Pleistocene prehistoric records preserved in the Kharga area, Gardner and Caton Thompson worked within constraints and the paradigms of their time. Comparative sequences were few, and it was assumed that lithic traditions 'progressed' through time in technology and morphology. One cultural unit defined at Bulaq has proven controversial: the 'Pre-Sebilian' or Khargan Industry [64]. The Khargan Unit used Levallois methodology for most cores and flakes; therefore, it was considered to be 'Middle Paleolithic'. Lacking stratified evidence, Caton Thompson considered that it probably preceded or overlapped with her 'Upper Paleolithic' Aterian Unit [36] (pp. 404-405). The enigmatic 'Site J' with built stone features and 'LevalloisoKhargan' lithics was discovered in 1931-32, high on the escarpment face, possibly because it lay on the northern end of Gardner's section line at Bulaq (Figure 10). On 30 January 1933, Gardner [58] made test excavations and a map, found the lithics both inside and outside the features-on the surface and in situ—and considered that the lithics could not be associated with the features, although Holocene evidence was lacking. Given the archeological knowledge of the Old World in 1933, an association of 'Middle Paleolithic' with stone features would have seemed highly improbable. 'Site J' was relocated in 2011 and investigation found that Caton Thompson had misread Gardner's field map, and located an additional feature with Khargan lithics [65].

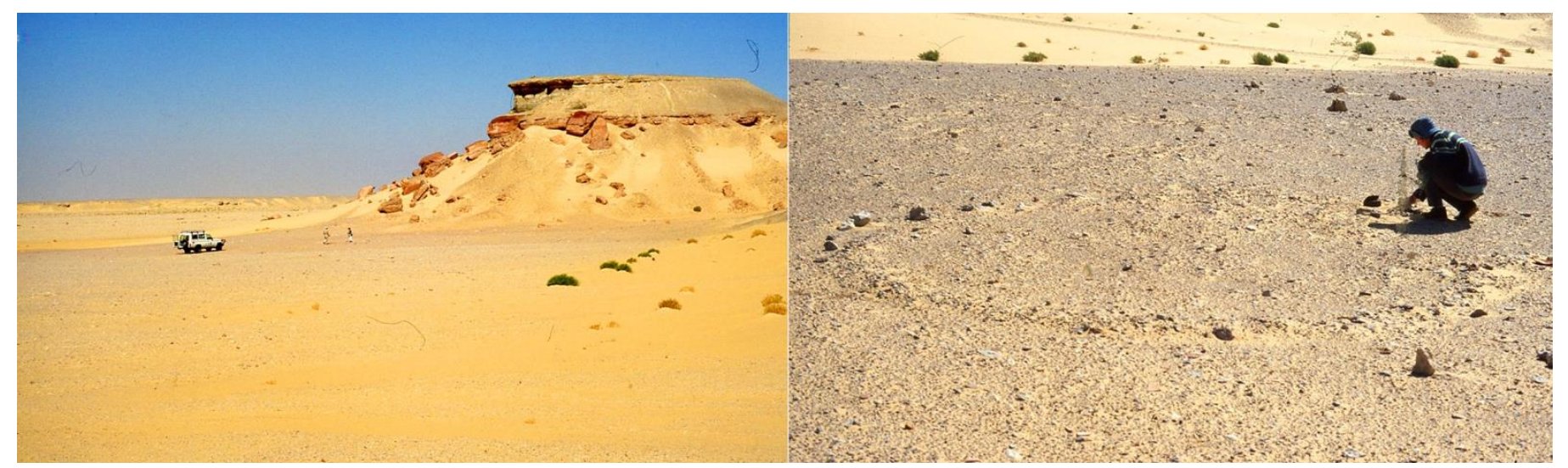

Figure 10. Bulaq campsites 1931-32. Left: Gardner and Caton Thompson campsite at the eastern edge of lowlands below foot terraces at Bulaq. Right: Gardner's tent circle. Person for scale located at rock sample discard pile. Photographed by MRK in 1998.

After many years, Gardner established a relative chronological sequence for springlaid tufa deposits on the escarpment in context with the associated artefacts and their Pleistocene archeological seriation, and she related the paleospring activity and environmental changes to water table changes and other depositional and erosional episodes [36,57]. In the lowlands, Gardner identified a sequence of foot terraces providing relative dating of fluvial activity. She systematically collected and later analyzed the fauna (mollusks) and vegetal (plant) impressions in sediments and paleospring tufas, comparing the mollusks from Fayum and other areas such as North Abydos (discussed below) and publishing an important comparative ecology study [39]. Gardner recognized, mapped and studied the formation processes in fossil artesian spring vents [36]. She also identified historic deposits now labeled 'irrigation sediments', and reconstructed the hydrology of historic wells and irrigation canals (also called qanats, which is the Arabic term) in related papers that Gardner published [38].

Gardner developed her geological observations in context of Caton Thompson's typological seriation; the artefactual associations and landscape stratigraphy helped correlate the relative timing of cultural activity and local hydroclimate change with Pleistocene glaciations $[12,66]$. Recent re-examination of their key localities and new analytical determinations using uranium series dating corroborates their ideas as mostly correct $([67,68]$ and references therein). The project in the Kharga Oasis had originally aimed to extend themes 
of work begun in the Fayum by further developing the relative prehistoric chronology of North Africa [63] (p. 370). In this regard, the Kharga research was successful; it provided a robust framework for later Quaternary research in both the Nile Valley and the desert, even after more detailed studies commenced in the 1960s (e.g., [54,69-78]).

\subsection{Abydos-Plateau and Nile Valley}

At the end of her 1931-1932 Kharga fieldwork, Gardner commenced a specific geological expedition near Gara to the north of Abydos [79]. She had raised her own funds from the Geological Society for a trip to specifically document paleospring limestone tufa deposits that preserved leaves and mollusk shells for comparison to those she had collected in Kharga and Fayum. Gardner was certainly motivated to pursue this work in response to Major H.J.L. Beadnell's [80] comments on Gardner's articles [36,81], in which he called for more robust comparison between fossil leaves and shells from Kharga and the Nile Valley. Caton Thompson [81] had defended Gardner from Beadnell's critiques while Gardner was working at Kharga during the time of publication and could not reply herself; however, Caton Thompson admitted that prior collection of leaves and shells from the Nile Valley had been on short visits. Gardner's trip to Abydos in 1932 was a concerted effort to collect more specimens to confirm associations she had made in her previous publications.

When back in London, Gardner researched at the Geological Society of London to identify the mollusk shells she meticulously recovered from sites across Egypt. She also studied comparative materials at Kew Gardens to confirm the identifications of the plant macrofossils and leaf impressions she had discovered in the sediments and spring mounds from Fayum, Kharga and in the Nile Valley. In 1935, Gardner published the results of her careful study and the implications for paleoecology in the desert in the Quarterly Journal of the Geological Society [39].

One notable incident during Gardner's fieldwork provides insight to her character. As recounted by Caton Thompson [15] (pp. 157-8): Gardner travelled away from basecamp, accompanied by a qufti (Arabic term for a skilled worker with field excavation and survey experience, usage originating with Flinders Petrie [82] (p. 2)), one camel driver and two camels - a male and a female. The female camel was in heat and the male tried to unseat Gardner by rolling over, from which she managed to fall clear, just in time. The male camel then attacked the camel driver and damaged his shoulder, and the qufti had to escort the camel driver with the female camel back to Abydos for medical aid. Caton Thompson recounts how "Elinor, practical as ever ... " continued her work and slept in her sleeping bag under a rock that night until the qufti returned with another camel-whereupon they continued to work another day before returning to base camp.

\section{Beyond Egypt: Anatolia and Palestine-The Levant and Judean Desert}

\subsection{Kusura}

Another long-standing relationship of Gardner was with Winifred Lamb, who had read Classics at Cambridge and was also at Newnham College [83]. Lamb had previously worked with the British School at Athens and was one of the founding members of the British Institute of Archeology at Ankara. In 1935, Gardner helped conduct a sondage at Kusura to help determine the potential of the site. That initial success led to two main seasons of excavation on site in 1936 and 1937, establishing it as an important early Bronze Age Site, and further enhancing Lamb's recognition as one of the leading authorities on the prehistory of Anatolia (modern-day Turkey).

\subsection{Bethlehem}

Gardner took part in excavations sponsored by the Wellcome Archeological Research Expedition to the Near East between 1935 and 1937. Gardner worked with the vertebrate paleontologist Dorothea Bate $[42,84]$ to study elephant-bearing bone beds that were discovered while digging a well in Bethlehem [85]. On 5 March 1935, Gardner first arrived on the site and immediately began to work, digging to enlarge the excavation pit in advance of 
Bate's arrival. When Bate joined the dig, the pit was significantly enlarged to 18-23 feet deep [42]. "EWG," as Bate came to call Gardner in her field notes, was keen to extend excavations. Gardner recorded the extent of the bone bed at a depth on photographically enlarged maps that she had especially made to emphasize the contours. Bate's notes also mention that Gardner documented the nature of the sedimentary matrix observed in the context of the recovered finds, including bone distributions and flints, some of which were initially identified as worked flakes [42].

From Bate's notes in March 1936, we know that Gardner obtained her driver's license in Palestine so that she could drive Starkey's $30 \mathrm{hp}-8$ cyl Ford. Bate mentions the occasional travels of "Miss G" into Jerusalem, taking visitors on drives and making trips to Jericho, the Dead Sea, Megiddo, Lachish and other archeological sites. After Caton Thompson flew in from Egypt on 24 March 1937, Gardner arranged for an extra driver to accompany her, Bate and Caton Thompson to Galilee and then Hula Valley to see the location of Jisr Banat Ya'qub, what is now known as Gesher Benot Ya'aqov, where the three ladies crossed the Jordan on a beautiful day [42] (p. 176).

In 1937, Gardner led a resulting Nature publication documenting the significance of the fossils at Bethlehem [86]. As mentioned above, there was some contention over the leadership of this excavation when Starkey took it over from Bate, but the authorship of the 1937 Nature article clearly shows who did the majority of the geological and paleontological research onsite. Faunal material recovered from the Bethlehem site yielded species of elephant and rhinoceros, including newly discovered species; the elephantine material represents the earliest known examples outside of Africa, as confirmed by later work (e.g., [87-89]).

Although Caton Thompson had not participated in the Bethlehem excavations, she studied the flints that Gardner and Bate had recovered in association with faunal material when she visited the site in 1937. A central question was whether these stones were natural or worked, flaked tools. Caton Thompson defined them as natural, and her assessment was noted in the Nature article [86]. This is important for understanding Gardner at this later career stage; despite Gardner's knowledge of archeology and experience working with lithic-bearing deposits, she asked Caton Thompson for her expert archeological opinion. Although this may have been out of respect, Caton Thompson offered an authoritative corroboration that supported Gardner's own interpretations. Despite a later suggestion that the Bethlehem faunal material had been modified by humans [90], past investigation [91] and recent analysis has found no evidence of bone modification by tools [88].

\subsection{Judean Desert}

In the mid-late 1930s, Gardner interacted with archeologists working in the Levant, Jordan Valley and greater region. "D. A. E. Garrod and E. W. Gardner were the first to observe and report the presence of handaxes..." and fossil fauna at a location in the Hula Valley at what became the amazing Acheulian site of Gesher Benot Ya'aqov ([92] as cited in [93]). Based on her extensive experience working in Egypt, Gardner would have easily recognized an Acheulian handaxe, and she was probably the one who explored the area, looking for associated archeozoological remains. The initial finds by Garrod and Gardner drew them a permit to excavate there in 1933 [42] (p. 262), and Garrod did more work in 1935 [94]. The abundant rich remains discovered at this critical site have yielded further insights about some of prehistoric archeology's most central issues, including the hominin control of fire [95].

\subsection{Wadi Ghazzad}

In 1938, Gardner undertook one season of work as part of the wider project by Flinders Petrie in the vicinity of Bronze Age-Iron Age Tell Fara in the southern Levant [96]. Starkey arranged the fieldwork, which consisted of a few days traversing the Wadi Ghazzad from Tell Fara to Um Gerar. Prior fieldwork by Petrie had found Aspatharia and Mutela, two genera of mollusks that were not known to occur outside of Africa. Gardner's objective 
was to document the mollusk species present in the area to understand whether those found in the previous excavation season were endemic, or traded to the area. Although she did not succeed in this specific goal, Gardner managed to identify some of the modern mollusk species present and to map the region; she synthesized her findings and described the topography and dry valley "wadi" deposits in a later volume chapter [96].

\section{Arabian Peninsula}

In the end of 1937, Caton Thompson and Gardner joined the famous travel writer Freya Stark in the "Wakefield Expedition" to the Arabian Peninsula, where they initiated the first systematic investigations of archeology in the Hadhramaut, Yemen [33,97-99]. Their work was partly funded by the Royal Geographical Society in London [32]. "The Wadi Hadhramaut, the second longest valley in Arabia and great trunk artery of the southwest, has many peculiar features which will keep physiographers happy for years to come," said Caton Thompson in her 9 November 1938 lecture to the Royal Central Asian Society [97] (p. 85). The area was so unknown to Europeans at the time that prior to the expedition, only two white women had been seen in the area before, one of whom was Stark, who wrote about her adventures in the 1940 book A Winter in Arabia [100].

The three members of the Wakefield Expedition were plagued by illness throughout the trip at various times, which slowed the work [33] (p. xi) and exacerbated a gradually increasing tension among the expedition members [101]. Personal and professional conflict emerged, with contentions around their methodological approaches. Stark presents this vividly in A Winter in Arabia as the 'Archeologist' character (a not-too-thinly disguised Caton Thompson) looking only at the ground and the archeological remains, while Stark preferred to talk to local people and consider their experience and expertise. While the reality was surely more nuanced, interpersonal conflicts escalated into something of a tug-of-war over Gardner's allegiances (see [102] (pp. 201-227)) with Gardner complaining in a letter home that they 'both wail to me!'. Feuding between the two warring sides continued for many decades following the expedition, both in correspondence and in publications (see [15,31,100-103]).

Despite operational troubles, the Wakefield Expedition was largely a success. The first part of The Tombs and Moon Temple of Hureidha (Hadhramaut) is written by Caton Thompson [33] (p. 9), but the examination and mapping was Gardner's work. In addition to doing her usual photography, surveying and cartography, Gardner investigated the fluvially-incised geology and she recognized defunct irrigation systems in the area of Wadi 'Amd and Wadi 'Adim, and the Wadi Hadhramaut. Gardner spent five days investigating the geology and related archeological material, and she interpreted that Wadi Hadramaut had formed in three major phases: erosional, depositional and erosional. Gardner's detailed observations greatly expanded knowledge of this area because only one other geological study had been undertaken by O. H. Little [104], who worked at a wadi located closer to the coast.

Gardner spent the remaining weeks at the Hadhramaut documenting the irrigation channels of Haudera at the Wadi 'Amd, along with their associated fields as well as other pre-Islamic sites in the area. The channels included a 20-30 m wide main feeder, the start of which may have commenced from a stone dam $\sim 16 \mathrm{~km}$ away [33] (p. 14). She recorded smaller channels, although some sections had been eroded away. Based on the mapping of these irrigation systems and features like dams, sluices and spill-ways, Gardner and Caton Thompson [33] (p. 12) calculated the amount of fertilized land and estimated a regional population during antiquity. Although irrigation channels are under-published in comparison with the excavated tombs and temples, they are archaeological sites that provide valuable insights about human activities for sustainability in this arid location.

\section{Conclusions}

Elinor Wight Gardner was a scientific pioneer who integrated field-based geological and Quaternary studies with archeology; she practiced geomorphological, paleoenviron- 
mental, botanical, zoological and excavational archeological studies throughout her career. Gardner's sustained commitment to collaborative interdisciplinary research helped her science to achieve a fully integrated geoarcheological approach across a range of spatial and temporal scales. She discovered and worked on multiple sites and on large-scale landscape surveys to identify multiple archeological localities. Gardner combined archeological and geological datasets to understand the environments of the past, and she provided some of the first and most important insights about human responses to Quaternary hydroclimate and landscape change in North Africa, Arabia and across the eastern Mediterranean. Additionally, she incorporated her expertise in paleontology and botany within these studies.

Gardner's robust geological training enabled her to develop and apply survey skills in her fieldwork, which enabled her to intuitively approach and document new landscapes at meaningful scales for both regional and archeological studies. She understood the semi-arid to hyperarid environments and rocky landscapes of her study areas. Gardner had a firm grasp of "site formation" - the processes by which archeological materials and matrices form and become preserved and/or disturbed, eroded, removed. Gardner described how landscapes formed over time, prior to human activity, and after, from prehistoric to historic times. Gardner was among the first geoscientists to recognize the value of studying fossil artesian spring vents as "draws" for humans and animal activities. Gardner participated in the survey and excavation of the paleosprings, and she recorded their stratigraphic details and reconstructed the processes that occurred in spring vents. Furthermore, she considered the site formation and how the spring processes themselves might affect the preservation of associated archeological artifacts [12].

Gardner was a successful field scientist who worked with many women archeologists during a timeframe when women were not commonly included in academic research and professional career pursuits. At the time of Gardner's education at Cambridge, women could study but not earn degrees; professional opportunities to develop skills of terrain measurement and observation were reserved mostly for those pursuing careers in the military, as prospectors for fossils, ores and petroleum, or those apprenticing in fields like mining geology, civil engineering and surveying. Field mapping in itself was rather challenging in the 1920-1930s; few women could manage the effort required to traverse and move heavy survey equipment across difficult terrain, and making measurements using a plane table or theodolite was tedious and slow. Because the remote areas where Gardner worked either lacked maps or had existing base maps that were unsuitable or were inaccurate in detail, Gardner endeavored to make her own contour maps. She used her own plane table, theodolite, survey rods and compass for triangulation and elevation calculations. Few people today can deploy these basic field survey methodologies to create new base maps, with even most modern land surveyors and civil engineers relying upon Global Positioning Systems (GPS) and satellite data.

The collaborators Gardner and Caton Thompson worked in difficult places to document prehistoric environments and the evidence left by people that lived in them. The corpus of Gardner's and Caton Thompson's interdisciplinary desert research was predicated upon the concept of 'habitability', with water availability as the limiting ecological factor in the desert regions where they worked. Gardner's efforts studying landscape elements, fossil flora, animal remains (mollusks) and artifacts associated with oases, former waterways (lakes, rivers) and carbonate springs brought new breadth and transformational insights. Gardner practiced what we now call "geoarcheology" — and she did so almost 50 years before geoarcheology was recognized by name and described as a worthy specialization. The individual and collaborative publications of the geologist Gardner and the archeologist Caton Thompson are wholly original and demonstrate genuine innovation in what is now known as cultural ecology, landscape archeology and geoarcheology.

It is worth noting that, during much of the early 21st century (especially between 1900-1950s), the specializations of geomorphology and Quaternary sciences were in their nascence. In her day, the topics that Gardner worked on were not considered valuable topics by many "real [male] geologists" with their traditions that focused on deep time, 
paleontology, hard rocks and mountains. As radiocarbon dating methods became established, and Ice Age research and "glacial stages" have become recognized as global events that can be correlated, the study of the Quaternary has also become much more appreciated by geologists [105-107]. Yet, in the 1930s, Gardner reconstructed the general scheme of the Late Quanternary, including the Plio-Pleistocene paleoclimatology in the Kharga Oasis by comparison with the original African 'four-stage' pluvial model [73,74]. Modern geochronological methods are providing absolute ages and refining Gardner's original relative dates inferred from strata and artefact seriation. But her ideas are generally correct [66-68].

One common refrain amongst scholars discussing the work of archeologists Gertrude Caton Thompson, Dorothea Bate, Dorothy Garrod and Winifred Lamb is that Elinor Wight Gardner was an important part of their work, "but we know little about her." This paper represents the first effort to compile details about Gardner's life and work. We wish to establish and recognize Gardner's position as a female pioneer in the geosciences at a time when women were denied university degrees and were rarely considered for permanent positions in the academy. The comparatively precarious position and financial pressures Gardner faced throughout her research career in the 1920s and 1930s, and until her eventual departure from academia, will resonate with many contemporary scholars. What Gardner was able to accomplish was impressive and she innovated, practiced and published great scientific works of geoarcheology commencing in the 1920s, well before geoarcheology was defined as its own specialization. Gardner's collaborative service has made significant contributions to geosciences, Quaternary studies and archeology, and her legacy as a woman scientist and transformative scholar must not be ignored. Without the hard work and transformative insights of Elinor Wight Gardner, the celebrated publications of those she worked with would not have received their lasting recognition.

Author Contributions: Conceptualization, K.N.; investigation, K.N., J.E., M.R.K., S.L.E. and R.P.; resources, K.N., J.E., M.R.K., S.L.E. and R.P.; writing—original draft preparation, K.N., J.E., M.R.K., S.L.E. and R.P.; writing - review \& editing, K.N., J.E. and M.R.K.; visualization, K.N., J.E., M.R.K. and S.L.E.; supervision, K.N.; project administration, K.N.; funding acquisition, K.N. All authors have read and agreed to the published version of the manuscript.

Funding: This research publication was funded by the University of Utah.

Institutional Review Board Statement: Not applicable.

Informed Consent Statement: Not applicable.

Data Availability Statement: Not applicable.

Acknowledgments: We credit University College London Special Collections and thank them for their permission to publish the images of Elinor Gardner. For access to the records of Gardner in their collections, we thank the Royal Geographical Society (with IBG) Archives, accessed through Wiley Digital Archives; we thank Nazlee Sabahipour for providing reference to Elinor Gardner's time at Offley Gardens; and we thank Philip Grover, Pitt Rivers Museum, Oxford for information about photographs in their archives, and for facilitating the scanning of Gardner's field notebooks for the Kharga Oasis Prehistory Project. Thanks also to David Gill, Sandra Pepelasis and Sian Tiley-Nel for help and clarification as we conducted this research. We also thank Caroline Lam of the Geological Society of London, Craig B. Smith of the Geological Society of South Africa and Stellenbosch University Emeritus Wilhelm J. Verwoerd, who kindly answered our research enquiries. Thanks to Professor Naama Goren-Inbar for information on Elinor's time in Palestine. Thanks also Sarah Walpole at the Royal Anthropological Institute (RAI) for granting permission to include the map in Figure 5. K.N. thanks Joy Wheeler at the RGS- with IBG for assistance with purchase of an academic license for reproducing Figure 6. K.N. also acknowledges and thanks those who supported her research in Egypt: the Royal Society UK, NASA Global Change Program, Smithsonian Institution and private donors. Over many years of fieldwork in Kharga, M.R.K. was supported by the Social Sciences and Humanities Research Council of Canada, the National Geographic Society, Washington, DC, the National Science Foundation, USA, the University of Toronto and by private donors. 
Conflicts of Interest: The authors declare no conflict of interest.

\section{References}

1. Renfrew, C. Archaeology and the Earth Sciences. In Geoarchaeology: Earth Science and the Past; Davidson, D.A., Shackley, M.I., Eds.; Duckworth: London, UK, 1976; pp. 1-5.

2. Wendrich, W. Getrude Caton Thompson (1888-1985). Famous Footsteps to Fill. Archéo-Nil 2007, 17, 89-106.

3. Weedman, K. Who's "That Girl”: British, South African, and American Women as Africanist Archaeologists in Colonial Africa (1860s-1960s). Afr. Archaeol. Rev. 2001, 18, 1-47. [CrossRef]

4. Vignaud, E. Une nouvelle industrie lithique: Le “Sebilien". BIFAO 1923, 22, 1-76.

5. Tristant, Y. Un savant et un esprit curieux. Le Pere Paul Bovier-Lapierre (1873-1950), pionnier de la prehistoire orientale. Archéo-Nil 2007, 17, 69-88.

6. Sandford, K.S.; Arkell, A.J. First Report of the Prehistoric Survey Expedition; University of Chicago Press: Chicago, IL, USA, 1928; Volume 3.

7. Sandford, K.S.; Arkell, W.J. The Relations of Nile and Faiyum in Pliocene and Pleistocene Times. Nature 1928, 121, 670-671. [CrossRef]

8. Sandford, K.S.; Arkell, A.J. Paleolithic Man and the Nile-Fayum Divide; University of Chicago Press: Chicago, IL, USA, 1929; Volume 10.

9. Sandford, K.S.; Arkell, A.J. Paleolithic Man and the Nile Valley in Nubia and Upper Egypt, A Study of the Region During Pliocene and Pleistocene Times; University of Chicago Press: Chicago, IL, USA, 1933; Volume 17.

10. Sandford, K.S.; Arkell, A.J. Paleolithic Man and the Nile Valley in Lower Egypt, With Some Notes Upon a Part of the Red Sea Littoral; University of Chicago Press: Chicago, IL, USA, 1939; Volume 46.

11. Bard, K.; Midant-Reynes, B.; Shaw, I. The Prehistory of Egypt: From the First Egyptians to the First Pharaohs. Int. J. Afr. Hist. Stud. 2001, 34, 197. [CrossRef]

12. Nicoll, K.; Giegengack, R.; Kleindienst, M. Petrogenesis of artifact-bearing fossil-spring tufa deposits from Kharga Oasis, Egypt. Geoarchaeology 1999, 14, 849-863. [CrossRef]

13. Vincent, A. Reclaiming the memory of pioneer female geologists 1800-1929. Adv. Geosci. 2020, 53, 129-154. [CrossRef]

14. Turner, S. Far-flung female (and fossil bone hunting) Fellows: An autoethnographical approach. Geol. Soc. Lond. Spec. Publ. 2021, 506, 277-302. [CrossRef]

15. Caton Thompson, G. Mixed Memoirs; The Paradigm Press: Gateshead, UK, 1983.

16. Haynes, C.V., Jr. The Geologist's Role in Pleistocene Palaeoecology and Archaeology. In The Reconstruction of Past Environments; Hester, J.J., Schoenwetter, J., Eds.; Fort Burgwin Research Center: Taos, NW, USA, 1964; pp. 61-64.

17. England \& Wales, National Probate Calendar, Index of Wills and Administrations 1958-1995 Elinor Wight Gardner. s. 1981 (Fox-Gimbert); 1981; p. 132.

18. England \& Wales, Civil Registration Death Index, 1916-2007, Elinor Wight Gardner; p. 341.

19. Wight, W.W. The Wights: A Record of Thomas Wight of Dedham and Medfield and of His Descendants, 1635-1890; Swain \& Tate: Milwaukee, WI, USA, 1890

20. U.S.A National Archives. Emilie Montgomery Gardner's U.S. Passport Application 1920 Roll 1206-Certificates: 33750-34125; 11 May 1920.

21. Tubb, J.; Burek, C.V. Gertrude Elles: The pioneering graptolite geologist in a woolly hat. Her career, achievements and personal reflections from her family and colleagues. Geol. Soc. London Spec. Publ. 2021, 506, 157-169. [CrossRef]

22. Scottish Successes in Cambridge Tripos. The Scotsman Newspaper, 21 June 1915.

23. Plug, C. S2A3 Biographical Database of Southern African Science. Available online: https://www.s2a3.org.za/bio/Biograph_ final.php?serial=2556 (accessed on 14 May 2021).

24. Nel, L.T. S. James Shand. In Transactions of the Geological Society of South Africa; Geological Society of South Africa: Johannesburg, South Africa, 1957; Volume LX, pp. 1-13. Available online: https://journals.co.za/doi/pdf/10.10520/AJA10120750_2228 (accessed on 21 June 2021).

25. Fourie-Basson, W. BSc Students' Field Trip in April 1918. Stellenbosch University News 01 March 2018. 2018. Available online: http:/ / www.sun.ac.za/english/Lists/news/DispForm.aspx?ID=5487 (accessed on 14 May 2021).

26. Dart, R.A. Guy Atwater Gardner, 1880-1959. S. Afr. Archaeol. Bull. 1960, 15, 3-4.

27. Caton Thompson, G.; Gardner, E.W. The Desert Fayum; The Royal Anthropological Institute of Great Britain and Ireland: London, UK, 1934.

28. Thompson, G.C. Captain Guy Gardner. Nature 1960, 185, 655-656. [CrossRef]

29. Caton Thompson, G. Guy Atwater Gardner: 1881-1959. Man 1960, 60, 56-57.

30. Harvey, J.; Ogilvie, M.B. Gardner, Elinor Wight (1892-1981). In The Biographical Dictionary of Women in Science: Pioneering Lives from Ancient Times to the Mid-20th Century; Ogilvie, M.B., Harvey, J., Eds.; Routledge: New York, NY, USA, 2000; pp. 483-484.

31. Evans, S.L. Terra incognita: Women on Royal Geographical Society Supported Expeditions 1913-1970; University of the West of England: Bristol, UK, 2015.

32. Evans, S.L. Mapping Terra Incognita: Women's Participation in Royal Geographical Society-Supported Expeditions 1913-1939. Hist. Geogr. Vol. 2016, 44, 30-44. 
33. Caton Thompson, G. The Tombs and Moon Temple of Hureidha (Hadhramaut); University Press: Oxford, UK, 1944.

34. Caton Thompson, G. Note dated 1975 and Appended as Frontispiece in Garner's Field Notebook: Gardner, E.W. (1931). E.W.G. Kharga. In Gardner Papers; Pitt Rivers Museum Manuscript Collections; University of Oxford: Oxford, UK, 1975.

35. Gardner, E.W. Kharga. February 1931 Flights, November 1931-January 1932, Mound Springs. In Gardner Papers; Pitt Rivers Museum Manuscript Collections; University of Oxford: Oxford, UK, 1932.

36. Gardner, E.W. Some Problems of the Pleistocene Hydrography of Kharga Oasis, Egypt. Geol. Mag. 1932, 69, 386. [CrossRef]

37. Gardner, E.W. Some Lacustrine Mollusca from the Faiyum Depression: A Study in Variation, Mémoires Présentés à l'Institut Égyptien; Imprimerie de l'Institut Français d'archéologie Orientale: Le Caire, Egypt, 1932.

38. Gardner, E.W. Notes on a temple at 'Ain Amur in the Libyan Desert. Anc. Egypt 1935, 108-109.

39. Gardner, E.W. The Pleistocene Fauna and Flora of Kharga Oasis, Egypt. Q. J. Geol. Soc. 1935, 91, 479-518. [CrossRef]

40. Gardner, E.W. Gardner's Letter to the GSL Dated 7 December 1938; Geological Society of London Archives: London, UK, 1938.

41. Garfinkel, Y. The Murder of James Leslie Starkey near Lachish. Palest. Explor. Q. 2016, 148, 84-109. [CrossRef]

42. Shindler, K. Discovering Dorothea: The Life of the Pioneering Fossil-Hunter Dorothea Bate; London Natural History Museum: London, UK, 2005.

43. Hillyard, A.M. From Offley Palace to Offley Place; A.M. Hillyard: Hertfordshire, UK, 1996.

44. Butzer, K.W. Geoarchaeology, climate change, sustainability: A Mediterranean perspective. In Geoarchaeology, Climate Change, and Sustainability; Brown, A.G., Basell, L.S., Butzer, K.W., Eds.; The Geological Society of America Special Paper: Boulder, CO, USA, 2011; Volume 476, pp. 1-14.

45. Champion, S. Women in British Archaeology: Visible and invisible. In Excavating Women: A History of Women in European Archaeology; Díaz-Andrew, M., Sørensen, M.L.S., Eds.; Routledge: London, UK, 1998; pp. 175-197.

46. Phillipps, R.; Holdaway, S.; Ramsay, R.; Emmitt, J.; Wendrich, W.; Linseele, V. Lake Level Changes, Lake Edge Basins and the Paleoenvironment of the Fayum North Shore, Egypt, during the Early to Mid-Holocene. Open Quat. 2016, 2, 118. [CrossRef]

47. Holdaway, S.J.; Wendrich, W. (Eds.) The Desert Fayum Reinvestigated: The Early to Mid-Holocene Landscape Archaeology of the Fayum North Shore, Egypt; Cotsen Institute of Archaeology Press at UCLA: Los Angeles, CA, USA, 2017.

48. Gardner, E.W. The Recent Geology of the Northern Fayum Desert. J. R. Anthropol. Inst. G. B. Irel. 1926, 61, 301-308. [CrossRef]

49. Gardner, E.W. The Recent Geology of the Northern Fayum Desert. Geol. Mag. 1927, 64, 386. [CrossRef]

50. Gardner, E.W. The Origin of the Northern Fayum Desert. Geol. J. 1927, 74, 373-383.

51. Gardner, E.W. The Origin of the Faiyum Depression: A Critical Commentary on a New View of Its Origin. Geogr. J. 1929, 74, 371. [CrossRef]

52. Caton-Thompson, G.; Gardner, E.W. Recent Work on the Problem of Lake Moeris. Geogr. J. 1929, 73, 20. [CrossRef]

53. Childe, V.G. New Light on the Most Ancient East; Routledge \& Kegan Paul: London, UK, 1958.

54. Wendorf, F.; Schild, R. Prehistory of the Nile Valley; Academic Press: New York, NY, USA, 1976.

55. Kleindienst, M.R. Some Observations on Palaeolakes and on Deposits at Kharga Oasis. In Oasis Papers 8; Duke University Press: Durham, NC, USA, 2020; pp. 107-118.

56. Caton Thompson, G. The Royal Anthropological Institute's Prehistoric Research Expedition to Kharga Oasis, Egypt. The second season's discoveries. Man 1932, 32, 129-135. [CrossRef]

57. Caton Thompson, G. Kharga Oasis in Prehistory; The Athlone Press: London, UK, 1952.

58. Gardner, E.W. Kharga. 1932-33. 'Ain Amur, Yebsa, E. Scarp. In Gardner Papers; Pitt Rivers Museum Manuscript Collections; University of Oxford: Oxford, UK, 1933.

59. Gardner, E.W. Letter of Elinor Gardner to 'Beloved' [Emilie Gardner], 14 December 1937; Royal Geographical Society (with IBG) Archives: London, UK, 1937.

60. Caton-Thompson, G. Kharga Oasis. Antiquity 1931, 5, 221-226. [CrossRef]

61. Gardner, E.W. Summary of Superficial Deposits and their Dating. In Kharga Oasis in Prehistory; Caton-Thompson, G., Ed.; The Athlone Press: London, UK, 1952; pp. 3-11.

62. Gardner, E.W. Notes on 'Ain 'Amur and Umm-ed-Dabadib. In Kharga Oasis in Prehistory; Caton-Thompson, G., Ed.; The Athlone Press: London, UK, 1952; pp. 11-14.

63. Caton-Thompson, G.; Gardner, E.W. The Prehistoric Geography of Kharga Oasis. Geogr. J. 1932, 80, 369. [CrossRef]

64. Kleindienst, M.R. The Khargan Complex vs. the 'Empty Desert Hypothesis', A Historical Perspective. In Oasis Papers 8; Duke University Press: Durham, NC, USA, 2020; pp. 77-106.

65. McDonald, M.M.; Wiseman, M.F.; Kleindienst, M.R.; Smith, J.R.; Taylor, N.; Wreschnig, A.J.; Skinner, A.R.; Blackwell, B.A. Did Middle Stone Age Khargan Peoples Leave Structural Features? 'Site J', The Forgotten Settlement of the 'Empty Desert', Kharga Oasis, Egypt: 1933 and 2011. J. Afr. Archaeol. 2016, 14, 155-179. [CrossRef]

66. Kleindienst, M.R.; Schwarcz, H.P.; Nicoll, K.; Churcher, C.S.; Frizano, J.; Gigengack, R.W.; Wiseman, M.F. Water in the desert: First report on Uranium-series dating of Caton-Thompson's and Gardner's "classic" Pleistocene sequence at Refuf Pass, Kharga Oasis. In The Oasis Papers 2. Proceedings of the Second International Conference of the Dakhleh Oasis Project; Wiseman, M.F., Ed.; Oxbow Books: Oxford, UK, 2008; pp. 25-54.

67. Hawkins, A.L.; Smith, J.R.; Giegengack, R.; McDonald, M.A.; Kleindienst, M.R.; Schwarz, H.P.; Churcher, C.S.; Wiseman, M.F.; Nicoll, K. New Research on the Prehistory of the Escarpment in Kharga Oasis, Egypt. Nyame Akuma 2001, 55, 8-14. 
68. Kleindienst, M.R. Pleistocene Geoarchaeological Surveys, Kharga Oasis Prehistory Project (KOPP), 2001-2011 plus others, Western Desert of Egypt. In The Oasis Papers 9. Tribute to Anthony J. Mills after Forty Years of Research in Dakhleh Oasis: Proceedings of the Ninth International Conference of the Dakhleh Oasis Project; Bowen, G.E., Hope, C.A., Parr, B., Eds.; Oxbow Books: Oxford, UK, 2019; pp. 37-88.

69. Butzer, K.W. Desert landforms at the Kurkur oasis, Egypt. Ann. Assoc. Am. Geogr. 1965, 55, 578-591. [CrossRef]

70. Vita-Finzi, C.; Butzer, K.W.; Hansen, C.L. Desert and River in Nubia: Geomorphology and Prehistoric Environments at the Aswan Reservoir. Geogr. J. 1969, 135, 264. [CrossRef]

71. Munson, P.J.; Wendorf, F.; Schild, R. Prehistory of the Eastern Sahara. Am. J. Archaeol. 1982, 86, 132. [CrossRef]

72. Wendorf, F.; Schild, R.; Close, A.E. Egypt during the Last Interglacial: The Middle Paleolithic of Bir Tarfawi and Bir Sahara East; Plenum Press: New York, NY, USA, 1993.

73. Nicoll, K. Radiocarbon chronologies for prehistoric human occupation and hydroclimatic change in Egypt and Northern Sudan. Geoarchaeology 2001, 16, 47-64. [CrossRef]

74. Nicoll, K. Recent environmental change and prehistoric human activity in Egypt and Northern Sudan. Quat. Sci. Rev. 2004, 23, 561-580. [CrossRef]

75. Nicoll, K. Geoarchaeological Perspectives on Holocene Climate Change as a Civilizing Factor in the Egyptian Sahara. In Climates, Landscapes, and Civilizations; Giosan, L., Fuller, D.Q., Nicoll, K., Flad, R.K., Clift, P.D., Eds.; Geopress, American Geophysical Union: Washington, DC, USA, 2012; pp. 157-162.

76. Macklin, M.G.; Toonen, W.H.; Woodward, J.; Williams, M.A.; Flaux, C.; Marriner, N.; Nicoll, K.; Verstraeten, G.; Spencer, N.; Welsby, D. A new model of river dynamics, hydroclimatic change and human settlement in the Nile Valley derived from meta-analysis of the Holocene fluvial archive. Quat. Sci. Rev. 2015, 130, 109-123. [CrossRef]

77. Nicoll, K.; Sallam, E.S. Paleospring tufa deposition in the Kurkur Oasis region and implications for tributary integration with the River Nile in southern Egypt. J. Afr. Earth Sci. 2017, 136, 239-251. [CrossRef]

78. Zerboni, A.; Nicoll, K. Enhanced zoogeomorphological processes in North Africa in the human-impacted landscapes of the Anthropocene. Geomorphology 2019, 331, 22-35. [CrossRef]

79. Gardner, E.W. Nile Valley. Gara and N. Abydos. In Gardner Papers; Pitt Rivers Museum Manuscript Collections; University of Oxford: Oxford, UK, 1932.

80. Beadnell, H.J.L. Remarks on the Prehistoric Geography and Underground Waters of Kharga Oasis. Geogr. J. 1933, 81, 128. [CrossRef]

81. Caton-Thompson, G. Mr. Beadnell's Remarks on the Prehistoric Geography and Underground Waters of Kharga Oasis: Comments and Replies. Geogr. J. 1933, 81, 134. [CrossRef]

82. Petrie, W.M.F. Koptos; Quaritch: London, UK, 1896.

83. Gill, D.W.J. 'A rich and promising site': Winifred Lamb (1894-1963), Kusura and Anatolian archaeology. Anatol. Stud. 2000, 50, 1-10. [CrossRef]

84. Shindler, K.A. Knowledge unique: The life of the pioneering explorer and palaeontologist, Dorothea Bate (1878-1951). In The Role of Women in the History of Geology; Burek, C.V., Higgs, B., Eds.; Geological Society: London, UK, 2007; pp. $295-303$.

85. Bate, D.M.A. Discovery of a Fossil Elephant in Palestine. Nat. Cell Biol. 1934, 134, 219. [CrossRef]

86. Gardner, E.W.; Bate, D.M.A. The Bone-Bearing Beds of Bethlehem: Their Fauna and Industry. Nature 1937, 140, 431-433. [CrossRef]

87. Hooijer, D.A. An early Pleistocene mammalian fauna from Bethlehem. Bulletin of the British Museum of Natural history, London. Geology 1958, 3, 265-292.

88. Rabinovich, R.; Lister, A. The earliest elephants out of Africa: Taxonomy and taphonomy of proboscidean remains from Bethlehem. Quat. Int. 2017, 445, 23-42. [CrossRef]

89. Pandolfi, L.; Rivals, F.; Rabinovich, R. A new species of rhinoceros from the site of Bethlehem: 'Dihoplus' bethlehemsis sp. nov. (Mammalia, Rhinocerotidae). Quat. Int. 2020, 537, 48-60. [CrossRef]

90. Stekelis, M. Interim Report to the Wellcome Trust; Wellcome Trust Archives: London, UK, 1940.

91. Clark, D.J. Fractured chert specimens from the Lower Pleistocene Bethlehem Beds, Israel; British Museum (Natural History): London, UK, 1961.

92. Stekelis, M. The Paleolithic deposits of Jisr Banat Yaqui. Bull. Res. Counc. Isr. 1960, G9, 61-87.

93. Goren-Inbar, N.; Alperson-Afil, N.; Sharon, G.; Herzlinger, G. The Acheulian Site of Gesher Benot Ya'aquv Volume IV: The Lithic Assemblages; Springer Nature: Cham, Switzerland, 2018.

94. Davies, W.; Charles, R. (Eds.) Dorothy Garrod and the Progress of the Palaeolithic; Oxbow: Oxford, UK, 2017.

95. Goren-Inbar, N.; Alperson, N.; Kislev, M.E.; Simchoni, O.; Melamed, Y.; Ben-Nun, A.; Werker, E. Evidence of Hominin Control of Fire at Gesher Benot Ya'aqov, Israel. Science 2004, 304, 725-727. [CrossRef]

96. Gardner, E.W. Traverse down Wady Ghazzeh. In City of the Shepherd Kings and Ancient Gaza; Petrie, W.M.F., Mackay, E.J.H., Murray, M.A., Eds.; British School of Egyptian Archaeology: London, UK, 1952; pp. 34-37.

97. Thompson, G.C. The Hadhramaut and its past. J. R. Central Asian Soc. 1939, 26, 79-92. [CrossRef]

98. Caton-Thompson, G.; Gardner, E.W. Climate, Irrigation, and Early Man in the Hadhramaut. Geogr. J. 1939, 93, 18. [CrossRef]

99. Caton-Thompson, G. Geology and Archæology of the Hadhramaut, South-west Arabia: Preliminary Notes on the Lord Wakefield Expedition. Nat. Cell Biol. 1938, 142, 139-142. [CrossRef]

100. Stark, F.A. Winter in Arabia: A Journey through Yemen; John Murray: London, UK, 1940. 
101. Sørensen, M.L.S. Rescue and Recovery: On historiographies of female archaeologists. In Excavating Women: A History of Women in European Archaeology; Díaz-Andrew, M., Sørensen, M.L.S., Eds.; Routledge: London, UK, 1998; pp. 31-60.

102. Geniesse, J.F. Freya Stark: Passionate Nomad; Chatto \& Windus: London, UK, 1999.

103. Izzard, M. Freya Stark: A Biography; Hodder \& Stoughton: London, UK, 1993.

104. Little, O.H. Geology and Geography of Mukalla (South Arabia); Egypt Geological Survey: Cairo, Egypt, 1919.

105. Baker, V.R. The pragmatic roots of American Quaternary geology and geomorphology. Geomorphology 1996, 16, 197-215. [CrossRef]

106. Ritter, D.F. Is Quaternary geology ready for the future? Geomorphology 1996, 16, 273-276. [CrossRef]

107. Gibbard, P.; Hughes, P. Terrestrial stratigraphical division in the Quaternary and its correlation. J. Geol. Soc. 2021, 178. [CrossRef]

\section{Short Biography of Authors}

Kathleen Nicoll is a Professor of Geography at the University of Utah with research interests in geomorphology, arid lands, and geoarchaeology. She was elected of Fellow of the Geological Society of America in 2011, and won the 2019 Career Award from its Geoarchaeology Division. Commencing from the time that she was an undergraduate student doing an honors thesis at the University of Pennsylvania, she has investigated the carbonate tufas documented by Elinor Wight Gardner and Gertrude Caton Thompson from Egypt. Nicoll completed an MA from Bryn Mawr College and a PhD from The University of Arizona before working for a bit as a petroleum geologist, before rejoining academia and winning a Royal Society Fellowship at Oxford University. She continues her work on geomorphology and archaeology field research projects in the Sahara, Turkey, Israel, and Namibia (to name a few places).

Joshua James Emmitt is a Post-Doctoral Research Fellow in the School of Social Sciences, Faculty of Arts, University of Auckland. He received his PhD in Anthropology from the University of Auckland in 2018, where his PhD investigated settlement pattern in middle-Holocene Egypt through pottery analysis. His current research is involved with projects examining data from New Zealand, Australia, Egypt, and Italy and has a focus on digital applications in archaeology. These projects include survey methods, 3D analysis, database management, and the integration of legacy data with contemporary analyses.

Maxine Rose Kleindienst is Professor Emerita, University of Toronto. HeB.A., Anthropology with honors minor in Geology, University of New Mexico, 1955 with distinction; M.A. (1956) and Ph.D (1959), Anthropology, University of Chicago. Museum research in southern Africa: 1959-60 NSF Postdoctoral fellowship, affiliated with University of Witwatersrand, Johannesburg. Published excavations at Middle Pleistocene Acheulian sites: Isimila, Tanzania (1957-58); Kalambo Falls, Zambia (1959, 1963); Olduvai Gorge, Bed III (1961-62). Egypt: Nubian survey (1964-65); Pleistocene archaeology and geoarchaeology, Western Desert, Dakhleh and Kharga oases (1986-2011+). As a faculty member (1973-1998) she taught on all three campuses of the University of Toronto, and was Chairman of the Department of Anthropology (1978-1986), retiring from the Mississauga campus. She is a founding member of the Society of Africanist Archaeologists, and is a life member of the Society for Archaeological Sciences and of Sigma Xi. Other fellowships and memberships were discontinued.

Sarah Evans is Research and Collections Engagement Manager at the Royal Geographical Society (with IBG). She carried out her doctoral research on the Society's Collections through an AHRC-funded Collaborative Doctoral Award. Her research examined women's participation in RGS-supported expeditions from 1913-1970, both mapping out the extent of that participation and then considering a number of women and their experiences in close detail. She has a particular interest in how we tell and write the histories of geography, fieldwork and exploration-and who is left out of these.

Rebecca Phillipps is a Senior Lecturer in Anthropology at University of Auckland. She received her PhD in Anthropology from the University of Auckland in 2012. Her research includes stone artefact analysis, digital methods of analysis, landscape archaeology, and archaeological theory. She is involved in archaeological and museum based projects in New Zealand and Egypt. 